Research article

\title{
Can isolated and riparian wetlands mitigate the impact of climate change on watershed hydrology? A case study approach
}

\author{
M. Fossey , A.N. Rousseau \\ INRS-ETE/Institut National de la Recherche Scientifique - Eau Terre Environnement, 490 rue de la Couronne, G1K 9A9 Quebec City, Quebec, Canada
}

\section{A R T I C L E I N F O}

\section{Article history:}

Received 21 February 2016

Received in revised form

14 August 2016

Accepted 14 September 2016

Available online $\mathrm{xxx}$

\section{Keywords:}

Isolated wetlands

Riparian wetlands

HYDROTEL

Watershed-scale modelling

Climate change

Hydrological indicators

\begin{abstract}
A B S T R A C T
The effects of wetlands on stream flows are well established, namely mitigating flow regimes through water storage and slow water release. However, their effectiveness in reducing flood peaks and sustaining low flows is mainly driven by climate conditions and wetland type with respect to their connectivity to the hydrographic network (i.e. isolated or riparian wetlands). While some studies have demonstrated these hydrological functions/services, few of them have focused on the benefits to the hydrological regimes and their evolution under climate change (CC) and, thus, some gaps persist. The objective of this study was to further advance our knowledge with that respect. The PHYSITEL/HYDROTEL modelling platform was used to assess current and future states of watershed hydrology of the Becancour and Yamaska watersheds, Quebec, Canada. Simulation results showed that CC will induce similar changes on mean seasonal flows, namely larger and earlier spring flows leading to decreases in summer and fall flows. These expected changes will have different effects on 20-year and 100-year peak flows with respect to the considered watershed. Nevertheless, conservation of current wetland states should: (i) for the Becancour watershed, mitigate the potential increase in 2-year, 20-year and 100-year peak flows; and (ii) for the Yamaska watershed, accentuate the potential decrease in the aforementioned indicators. However, any loss of existing wetlands would be detrimental for 7-day 2-year and 10-year as well as 30day 5 -year low flows.
\end{abstract}

๑) 2016 Elsevier Ltd. All rights reserved.

\section{Introduction}

Wetlands have been recognized for their significant role on the hydrological cycle through water storage and slow release of water (Ogawa and Male, 1986; Padmanabhan and Bengtson, 2001; Liu et al., 2008; Wang et al., 2008; Wu and Johnston, 2008; Yang et al., 2010). Despite this general agreement, approximately half of their spatial extent has been lost worldwide (Zedler and Kercher, 2005). With the largest agricultural activity (Jobin et al., 2004) and the most populated region of Quebec (Li and Ducruc, 1999), Canada, the St. Lawrence Lowlands are characterized by several heavily affected ecosystems and among them, wetlands are no exception with almost $45 \%$ of affected areas (Joly et al., 2008). Their degradation or conversion in response to increase human activities (e.g., agriculture, peat mining, and urbanization) is well known as one of the key disturbances of watershed hydrology and impairment to the global environment (Solomon et al., 2007). Thenceforward,

\footnotetext{
* Corresponding author.

E-mail address: maxime.fossey@ete.inrs.ca (M. Fossey).
}

their deterioration may have severe impacts on flow regimes (i.e., watershed hydrology) inducing a positive feedback under climate change conditions.

Hydrological modelling has proven to be a useful framework to asses climate change impacts on wetlands (Fu et al., 2015; Fossey and Rousseau, 2016) or watershed hydrology (Quilbé et al., 2008; Boyer et al., 2010) and to illustrate the impacts of these landscape features on flow regimes (Wang et al., 2010; Martinez-Martinez et al., 2014; Golden et al., 2015; Evenson et al., 2015; Fossey et al., 2016). However, some gaps persist regarding the evolution of wetland impacts on watershed hydrology under changing climate conditions. Over the last decade, scientific knowledge on future climate impacts in Quebec, Canada, has advanced and expected changes are well identified (Ouranos, 2015). Indeed, in the St. Lawrence Lowlands, projected annual temperatures may increase by $2-4{ }^{\circ} \mathrm{C}$ for the period $2040-2070$. While the total annual precipitation may be relatively constant, seasonal modifications are expected, particularly in winter. The decrease in snowfall and the increase in rainfall during this season will affect stream flows (Appendix A). Indeed, the increase in mean temperature and the 
associated decrease in the ratio of snow to liquid precipitation should lead to an increase in the amount of water available for winter flows and a decrease in snow water equivalent reducing spring, summer and fall flows (Boyer et al., 2010).

These expected changes and resulting impacts on water availability, and thus on the water balance at the watershed scale, may affect wetlands. Indeed, the quantity and periodicity of wetland inflows could be affected. In return, wetlands could be more vulnerable and their hydrological functions and/or physical integrity be threatened (Erwin, 2009; Hebb et al., 2013; Fossey and Rousseau, 2016). Nevertheless, some questions arise such as: (i) What is the contribution of wetlands to current flow regimes? (ii) How will the role of wetlands evolve under changing climate conditions? (iii) Will their impacts on watershed hydrology be modified in the future?; and (iv) If wetlands are vulnerable, what will be the impact on the hydrological regime?

Using a distributed hydrologic modelling platform, this study assesses: (i) the current contribution of wetlands to stream flow and (ii) the expected changes at the outlet of two key watersheds of the St. Lawrence lowlands, namely those of the Becancour and Yamaska Rivers. This assessment, through analysis of some commonly used hydrologic indicators (i.e., $\mathrm{Q}_{\max }, \mathrm{Q}_{7}$ and $\mathrm{Q}_{30}$ ) provides a framework to distinguish climate change and wetland (i.e., isolated and riparian) effects on watershed hydrology. It also highlights the potential benefits of wetlands under changing climate conditions.

\section{Methods}

\subsection{Study areas}

Based on criteria related to land cover representativeness and wetland diversity, two watersheds were selected: the Becancour and Yamaska River watersheds. They cover $2597 \mathrm{~km}^{2}$ and $4788 \mathrm{~km}^{2}$ in the St. Lawrence Lowlands ecoregion (Mackey et al., 1996; McKenney, 1998) in southern Quebec, Canada, respectively (Fig. 1). Tributaries of the St Lawrence River, the Becancour and Yamaska Rivers drain landscapes dominated by forest (54\% and $35 \%$. respectively), agriculture (23\% and $41 \%$ ), and wetlands ( $12 \%$ and 4\%) (Beaulieu et al., 2012). As introduced in Table 1, in the Becancour watershed, wetlands cover a total area of $307 \mathrm{~km}^{2}$ and drain $794 \mathrm{~km}^{2}$ (31\% of the watershed). Among them, isolated wetlands (IWs) occupy $210 \mathrm{~km}^{2}(8 \%)$ and drain $464 \mathrm{~km}^{2}(18 \%)$ while riparian wetlands (RWs) occupy $97 \mathrm{~km}^{2}$ (4\%) and drain $330 \mathrm{~km}^{2}$ (13\%). In the Yamaska watershed, wetlands cover a total area of $202 \mathrm{~km}^{2}$ including $92 \mathrm{~km}^{2}$ (2\%) of IWs and $110 \mathrm{~km}^{2}$ (2\% of the watershed) of RWs. From another point of view, the Yamaska wetlands drain $646 \mathrm{~km}^{2}$ (13\%) including $305 \mathrm{~km}^{2}$ (6\%) drain by IWs and $341 \mathrm{~km}^{2}(7 \%)$ by RWs.

Located in a humid continental climate (Köppen-Geiger classification:Dfb - Peel et al., 2007), the watersheds are characterized by warm summers and severe winters with strong seasonality. Normal conditions for the 1981-2010 period (MDDELCC, 2014) are associated with an annual mean temperature of $5.1^{\circ} \mathrm{C}$ with an average maximum of $19.3^{\circ} \mathrm{C}$ in July and an average minimum of $-11.2^{\circ} \mathrm{C}$ in January. The total mean annual precipitation is $1210 \mathrm{~mm}$, including $953 \mathrm{~mm}$ of liquid precipitation and $257 \mathrm{~mm}$ of solid precipitation (Appendix A). For the Becancour and Yamaska watersheds, the specific average monthly values of climate statistics are reported in Appendix B.

\subsection{Hydrologic modelling platform}

\subsubsection{Model description}

The PHYSITEL/HYDROTEL distributed hydrological modelling platform was used to evaluate the expected changes due to climate change and to assess the effects of wetland types on watershed hydrology; quantifying their respective contribution to the flow regime (Fossey et al., 2015). More specifically, PHYSITEL is a specialized GIS and HYDROTEL is a continuous distributed hydrologic model (Turcotte et al., 2001, 2003, 2007; Fortin et al., 2001; Rousseau et al., 2011; Bouda et al., 2012, 2014; Noël et al., 2014). The model is currently used for inflow and hydrological forecasting at Hydro-Quebec, Quebec's primary power utility, and the Quebec Hydrological Expertise Centre (Centre d'Expertise Hydrique du Québec, CEHQ). This modelling platform can explicitly account for isolated (IWs) and riparian wetlands (RWs) (Fossey et al., 2015), using the Hydrologically Equivalent Wetland (HEW) concept (Liu et al., 2008; Wang et al., 2008). The basic computational units used by HYDROTEL and discretized using PHYSITEL correspond to Relatively Homogeneous Hydrological Units (RHHUs: subwatersheds or hillslopes) and interconnected river segments (Fig. 2).

For this study, the two watersheds were discretized as follows: the Becancour and Yamaska watersheds, into 1824 and 1299 hillslopes (mean surface areas of $2.6 \mathrm{~km}^{2}$ and $7.3 \mathrm{~km}^{2}$, respectively), and 736 and 513 river segments (mean length of $1179 \mathrm{~m}$ and $1623 \mathrm{~m}$ ), respectively. Similarly, the watersheds were discretized into 859 and 498 isolated HEWs (mean surface areas of $0.24 \mathrm{~km}^{2}$ and $0.22 \mathrm{~km}^{2}$, respectively) and 444 and 296 riparian HEWs (mean surface areas of $0.22 \mathrm{~km}^{2}$ and $0.31 \mathrm{~km}^{2}$ ), respectively.

\subsubsection{Model set up}

HYDROTEL was run using a daily time step and basic meteorological data (i.e., precipitation, minimum and maximum temperatures obtained from CEHQ for the 1961-2010 period). Meanwhile for this study, the simulated daily stream flows at the outlet corresponded to the output of interest. Model calibration and validation were done using a manual trial-and-error strategy (Turcotte et al., 2003) over different five-year intervals of the 1969-2010 period while using 1-year spin-up period to minimize initialization errors (for a complete overview, see Fossey et al., 2015). Both temporal and spatial validations were performed, allowing a quantitative and qualitative verification of simulated flows. Statistics for calibration and validation periods are reported in Table 2.

\subsubsection{Theoretical background}

The addition of wetlands module has improved the model's ability to accurately reproduce the basic components of hydrograph (i.e., magnitude, frequency, timing and duration of water conditions) as reported in Fossey et al. (2015) for the Becancour watershed. These performance improvements increased the values of statistical indices from approximately $13 \%$ and $8 \%$ for the Becancour and the Yamaska (Rousseau et al., 2008, 2012) watersheds, respectively. Meanwhile, with respect to the hydrological modelling approach used for the Becancour watershed (Fossey et al., 2016), the impacts of wetlands depend on both their type (i.e., isolated or riparian) and their geographic location within a watershed (i.e., upstream/downstream gradient and stream order gradient). Moreover, for a given type and location, the results under similar hydro-climatic conditions illustrate the highly individualized and contrasting (i.e., positive or negative impacts) response that wetlands can exhibit as reported by Nilsson et al. (2013).

\subsection{Climate scenarios}

Daily climatic data for the 1961-2099 period were supplied by Ouranos, a Consortium on Regional Climatology and Adaptation to Climate Change. Ten simulations of the Canadian Regional Climate Model (CRCM $4 \times$ ) (Caya and Laprise, 1999; Music and Caya, 2007; 


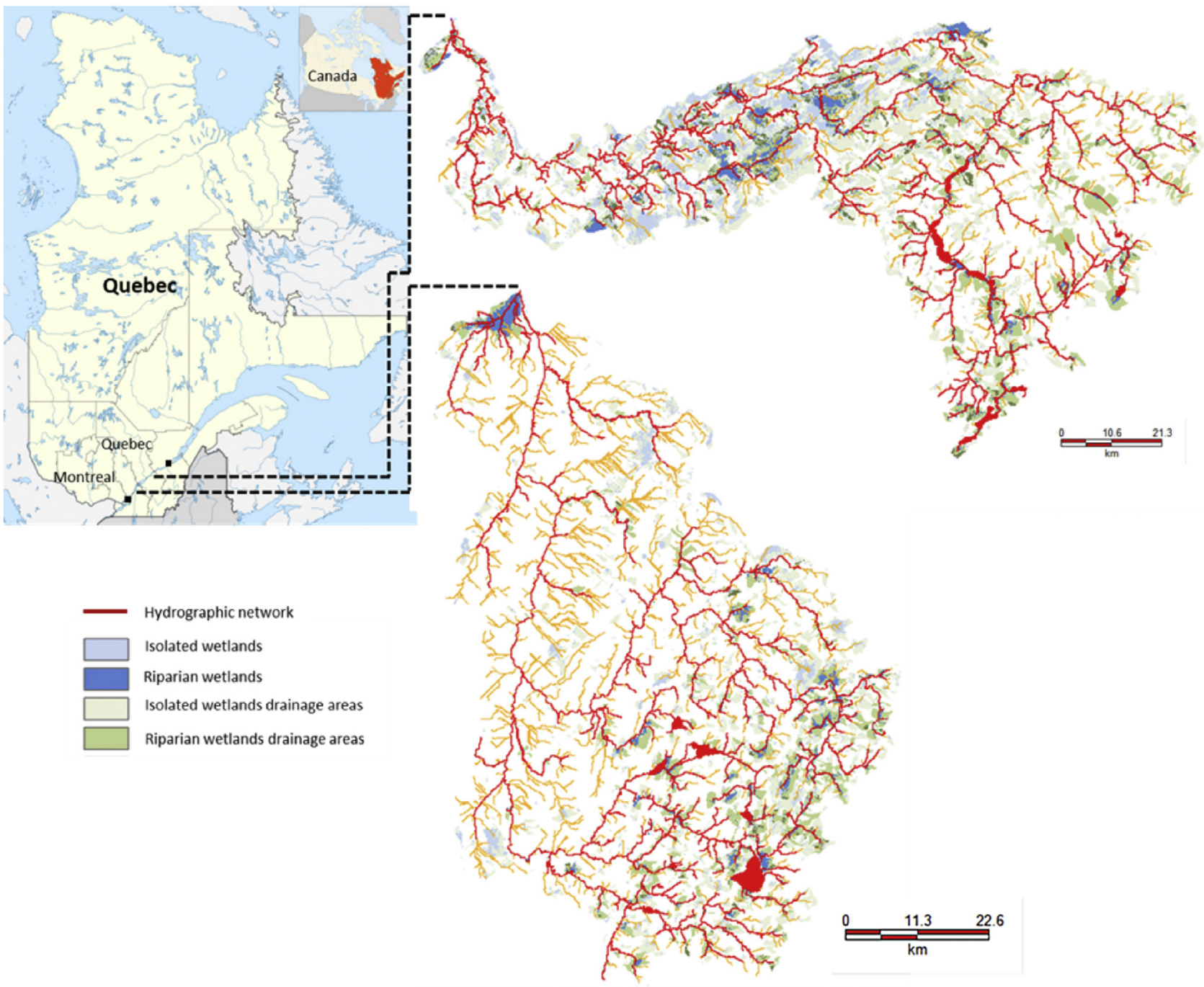

Fig. 1. Geographic locations of the Becancour River and Yamaska River watersheds, Quebec, Canada.

Table 1

Physical and wetlands statistics for the Becancour and Yamaska River watersheds.

\begin{tabular}{|c|c|c|c|c|c|c|c|c|c|}
\hline \multirow[t]{2}{*}{ Watershed } & \multirow[t]{2}{*}{ Surface $\left(\mathrm{km}^{2}\right)$} & \multicolumn{5}{|c|}{ Land cover (\%) } & \multicolumn{3}{|l|}{ Wetland area } \\
\hline & & Forest & Agric & ure & Bush & Urban & Total km² (\%) & Isolated km² (\%) & Riparian $\mathrm{km}^{2}(\%)$ \\
\hline Becancour & 2597 & 53.9 & 23 & & 5.6 & 3.5 & 307 (12) & $210(8)$ & $97(4)$ \\
\hline \multirow[t]{3}{*}{ Yamaska } & 4788 & 34.6 & 43.1 & & 9.3 & 7.3 & $202(4)$ & $92(2)$ & $110(2)$ \\
\hline & \multicolumn{6}{|c|}{ Physical characteristics } & \multicolumn{3}{|c|}{ Wetland drainage area } \\
\hline & Average slope (\%) & \multicolumn{2}{|l|}{ Main soils } & \multicolumn{2}{|c|}{ Gravelius index } & Drainage density $^{\mathrm{a}}$ & Total km & Isolated $\mathrm{km}^{2}(\%)$ & Riparian $\mathrm{km}^{2}(\%)$ \\
\hline Becancour & \multirow{2}{*}{$\begin{array}{l}0.5 \\
0.7\end{array}$} & \multirow{2}{*}{\multicolumn{2}{|c|}{$\begin{array}{l}\text { Sandy loam-loam } \\
\text { Silt loam-sandy loam }\end{array}$}} & \multicolumn{2}{|c|}{2.3} & 0.52 & $794(31)$ & $464(18)$ & $330(13)$ \\
\hline Yamaska & & & & 1.7 & & 0.50 & $646(13)$ & $305(6)$ & $341(7)$ \\
\hline
\end{tabular}

(\%) is the area or drainage area of wetland expressed in percentage.

${ }^{\text {a }}$ Horton concept $=\Sigma$ length of river $(\mathrm{km}) /$ watershed area $\left(\mathrm{km}^{2}\right)$.

Paquin, 2010; de Elia and Côté, 2010) using the A2 greenhouse gas and aerosol projected scenarios of the Special Report on Emission Scenarios (SREAS-A2) (Nakicenvoic et al., 2000) were used in this study. Note that these simulations were deemed representative of a myriad of potential climate changes using the cluster method (Hartigan and Wong, 1979) and considered equally probable. Climatic data may have a bias in the estimation of climate variables (i.e., constant overestimation or underestimation trend) and then require post-treatment. The CRCM simulations were bias-corrected by a factor calculated from a comparison between the simulated reference period and the observed data. The bias was then removed on the entire simulated series.

These unbiased CRCM simulations were driven by two Global Climate Models (GCMs); that is two members (i.e., initial conditions 


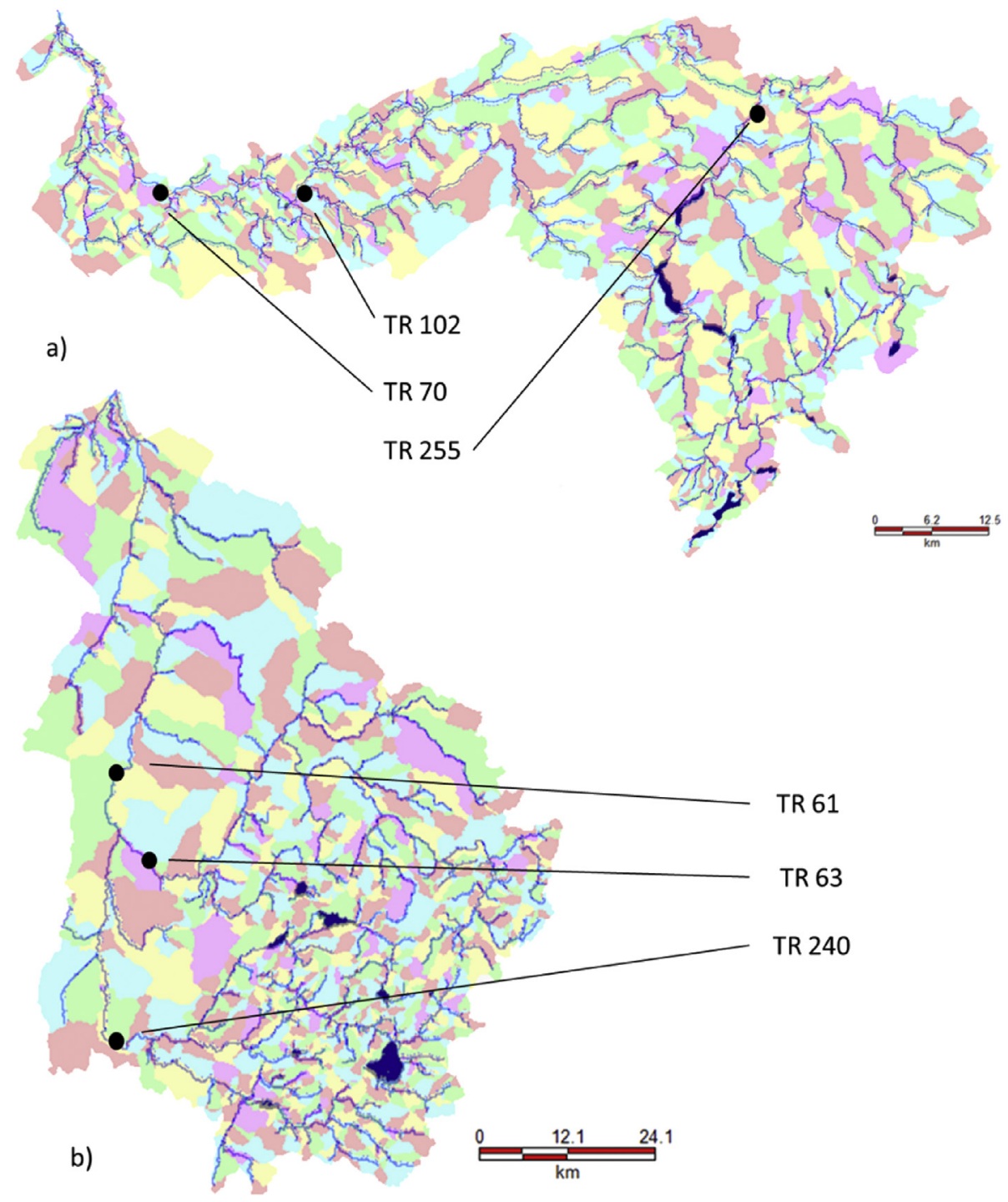

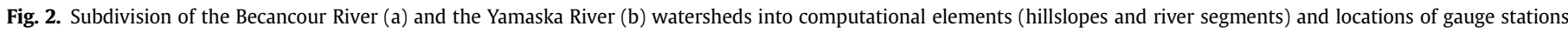

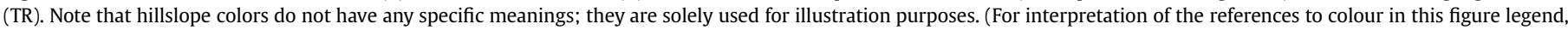
the reader is referred to the web version of this article.)

Table 2

Model performances for calibration and validation periods.

\begin{tabular}{|c|c|c|c|c|c|c|}
\hline \multirow[t]{2}{*}{ Watershed } & \multirow[t]{2}{*}{ Stream flow station } & \multirow[t]{2}{*}{ Period } & \multicolumn{3}{|c|}{ Statistical performance } & \multirow[t]{2}{*}{ Objective } \\
\hline & & & NSE & $\operatorname{RMSE}\left(\mathrm{m}^{3} / \mathrm{s}\right)$ & Pbias (\%) & \\
\hline \multirow[t]{5}{*}{ Becancour } & TR_70 & 1988-1992 & 0.78 & 13.9 & -4.4 & Spatio-temporal validation \\
\hline & TR_102 & 2005-2009 & 0.77 & 28.3 & -5.5 & Calibration \\
\hline & & $2000-2004$ & 0.80 & 24.3 & 2.6 & Temporal validation \\
\hline & TR_255 & 2005-2009 & 0.78 & 13.9 & -4.4 & Calibration \\
\hline & & 1999-2004 & 0.86 & 9.3 & 6.6 & Temporal validation \\
\hline \multirow[t]{6}{*}{ Yamaska } & TR_61 & $2005-2010$ & 0.78 & 42.9 & 0.1 & Calibration \\
\hline & & $2000-2005$ & 0.78 & 38.3 & -13 & Temporal validation \\
\hline & TR_63 & $2005-2010$ & 0.73 & 23.7 & 2.5 & Calibration \\
\hline & & $2000-2005$ & 0.71 & 21.9 & -14.2 & Temporal validation \\
\hline & TR_240 & $2005-2010$ & 0.75 & 16.0 & -2.5 & Calibration \\
\hline & & $2000-2005$ & 0.77 & 14.4 & -13.6 & Temporal validation \\
\hline
\end{tabular}

of driver) for the third generation Canadian Coupled Global Climate Model - CGCM3 (Flato et al., 2000; Flato and Boer, 2001; Scinocca et al., 2008) and one for the German coupled Global Climate
Model - ECHAM5 (Jungclaus et al., 2006) over a domain covering North America or centred over Quebec both with a horizontal gridsize mesh of $45 \mathrm{~km}$. An overview of the technical characteristics of 
Table 3

CRCM versions and characteristics of simulations.

\begin{tabular}{|c|c|c|c|c|c|c|c|c|c|c|}
\hline Operational name & acu & adc & adj & adl & aet & aev & afx & agr & $\operatorname{agx}$ & aha \\
\hline CRCM version & 4.1 .1 & 4.1 .1 & 4.2 .0 & 4.2 .0 & 4.2 .3 & 4.2 .3 & 4.2 .3 & 4.2 .3 & 4.2 .3 & 4.2 .3 \\
\hline Driving data & CGCM3 & CGCM3 & CGCM3 & CGCM3 & CGCM3 & CGCM3 & CGCM3 & CGCM3 & ECHAM5 & ECHAM5 \\
\hline Member & 4 & 5 & 4 & 5 & 4 & 5 & 4 & 5 & 1 & 1 \\
\hline Regional domain & Quebec & Quebec & Quebec & AMNO & AMNO & AMNO & Quebec & Quebec & AMNO & Quebec \\
\hline
\end{tabular}

these scenarios is reported in Table 3. For the 2040-2070 period, the same meteorological variables as those described for the 1981-2010 period (cf. section 2.1 Study areas), were analysed and compiled. The average monthly values of climate statistics, with respect to the Becancour and Yamaska watersheds, for this future period (2040-2070) and integrating the ten simulations, are reported in Appendix C and Appendix D respectively.

\subsection{Assessment of the impact of wetlands on watershed hydrology}

This assessment was defined and based on wetland typologies (i.e., IWs versus RWs) stemming from the hydrogeomorphic (HGM) approach for landscape planning (Brinson, 1993, 2009). Four wetland-based simulations were performed accounting for: (i) all wetlands (WT), (ii) isolated wetlands (IW), (iii) riparian wetlands (RW), and finally without any wetlands (WW). The latter was defined as the reference simulation. For each simulation, there was one model run from 1979 to 2010 and another from 2039 to 2070 with the first year used as a spin-up period.

The assessment was determined through the analysis of daily stream flows at the watershed outlet in terms of seasonal mean stream flow and of two sets of frequently-used stream flow parameters: (i) a first set corresponding to three high-flow indicators, the 2-year $\left(\mathrm{Q}_{2}\right)$, 20-year $\left(\mathrm{Q}_{20}\right)$ and 100-year $\left(\mathrm{Q}_{100}\right)$ daily maximum flow $\left(\mathrm{Q}_{\max }\right)$, and (ii) the other set made up of three low-flow indicators, the 2-year $\left(\mathrm{Q}_{2-7}\right)$ and 10-year $\left(\mathrm{Q}_{10-7}\right)$ minimum flows over seven consecutive days and the 5 -year $\left(\mathrm{Q}_{5-30}\right)$ minimum flow over 30 consecutive days. These hydrological indicators were determined from a log-normal distribution which was selected based on the BIC (Bayesian information criterion) (Schwarz, 1978).

The impact of wetlands was expressed as a variation (\%) of the calculated indicator for a given wetland-based simulation (WT, IW or RW) compared to the same indicator calculated on the basis of the WW simulation. This impact can be expressed as follows:

$W I_{x, j}=100 \times\left[\frac{\left(H I_{x, j}-H I_{w w}\right)}{H I_{w w}}\right]$

where $\operatorname{WII}_{x, j}(\%)$ is the wetland impact indicator for simulation $(x)$ for given climatic conditions $j$ (i.e., current $-c$ - or future $-f$-); $H I_{x, j}$ is the hydrological indicator calculated for the considered wetlandbased simulation $(x)$ and climatic condition $j$, and $H I_{w w}$ is the hydrological indicator calculated for the reference wetland-based simulation (i.e., for the without any wetland case).

\section{Results and discussion}

\subsection{Model performance}

The Nash-Sutcliffe efficiency (NSE) (Nash and Sutcliffe, 1970) criterion, the root-mean-squared error (RMSE) (Singh et al., 2004), and the percentage bias (Pbias) (Yapo et al., 1996) were used to assess model performance. As reported in Table 2, the NSE criterion values are greater than 0.75 for the Becancour watershed and greater than 0.70 for the Yamaska watershed either for the period of calibration or that of validation. The Pbias values are less than $10 \%$ except for the validation period of the Yamaska watershed where they range from $-10 \%$ to $-15 \%$. These negative values may reflect a slight tendency of the model to underestimate the flows. The RMSE calculated for each gauge station shows a relatively stable error. According to the hydrologic model performance rating described by Moriasi et al. (2007), the model calibration may be considered very good (NSE > 0.75 and Pbias < 10\%) to good (NSE $>0.65$ and Pbias $<15 \%$ ).

\subsection{Hydrology of the study watersheds under current and future climatic periods}

As shown in Fig. 3, when compared to the mean simulated hydrograph characterizing the current period (1980-2010), each mean simulated hydrograph obtained for the future period (2040-2070) presents higher flows during winter and lower flows in spring, summer and fall. These results are consistent with those of Boyer et al. (2010). Also, simulations indicate shifts and decreases in future spring floods. Summer and fall flows tend to be lower according to: (i) the shift of the spring flood period, (ii) the decrease in snowpack, reducing the period during which the water is available for flows, and (iii) the slight decrease in rainfall. Note that evapotranspiration may be time-varying due to the potential early growing period (Badeck et al., 2004) and decrease, to some extent, the water available for flows. Considering the mean seasonal specific flows (i.e., flow per unit area $-\mathrm{m}^{3} / \mathrm{s} / \mathrm{km}^{2}$ ) for the current period, despite being twice as large as the Becancour watershed, the flows of the Yamaska watershed are of the same order (0.011-0.013) as those of the Becancour during summer and fall. Meanwhile for winter, the flow of the Yamaska is nearly twice as large $(0.014)$ as that of the Becancour (0.008). Contrariwise, for spring, the mean flow of the Becancour watershed is larger $(0.035)$ than that of the Yamaska (0.024). These results suggest that the Becancour watershed has a more variable flow regime when compared to that of the Yamaska which presents a more stable specific flow throughout the year apart from that of spring. Thenceforth, the expected changes due to CC vary from one watershed to another. More precisely, for the Becancour watershed, these variations range from $75 \%$ to $119 \%$ (winter), from $-24 \%$ to $-5 \%$ (spring), from $-44 \%$ to $-34 \%$ (summer) and from $-42 \%$ to $-18 \%$ (fall). For the Yamaska watershed, they are from $56 \%$ to $68 \%$ (winter), $-8 \%-19 \%$ (spring), $-43 \%$ to $-26 \%$ (summer) and $-43 \%$ to $-15 \%$ (fall). The differences observed during winters and springs are the result of the dynamics of snow processes (i.e., modifications of snow accumulations, ratio of solid to liquid precipitation, maximum and minimum temperatures) mainly driven by local climatic conditions and some physical characteristics of watersheds (e.g., size, shape, drainage density, etc.) which could be factors decreasing or increasing their sensitivity to local weather conditions. 

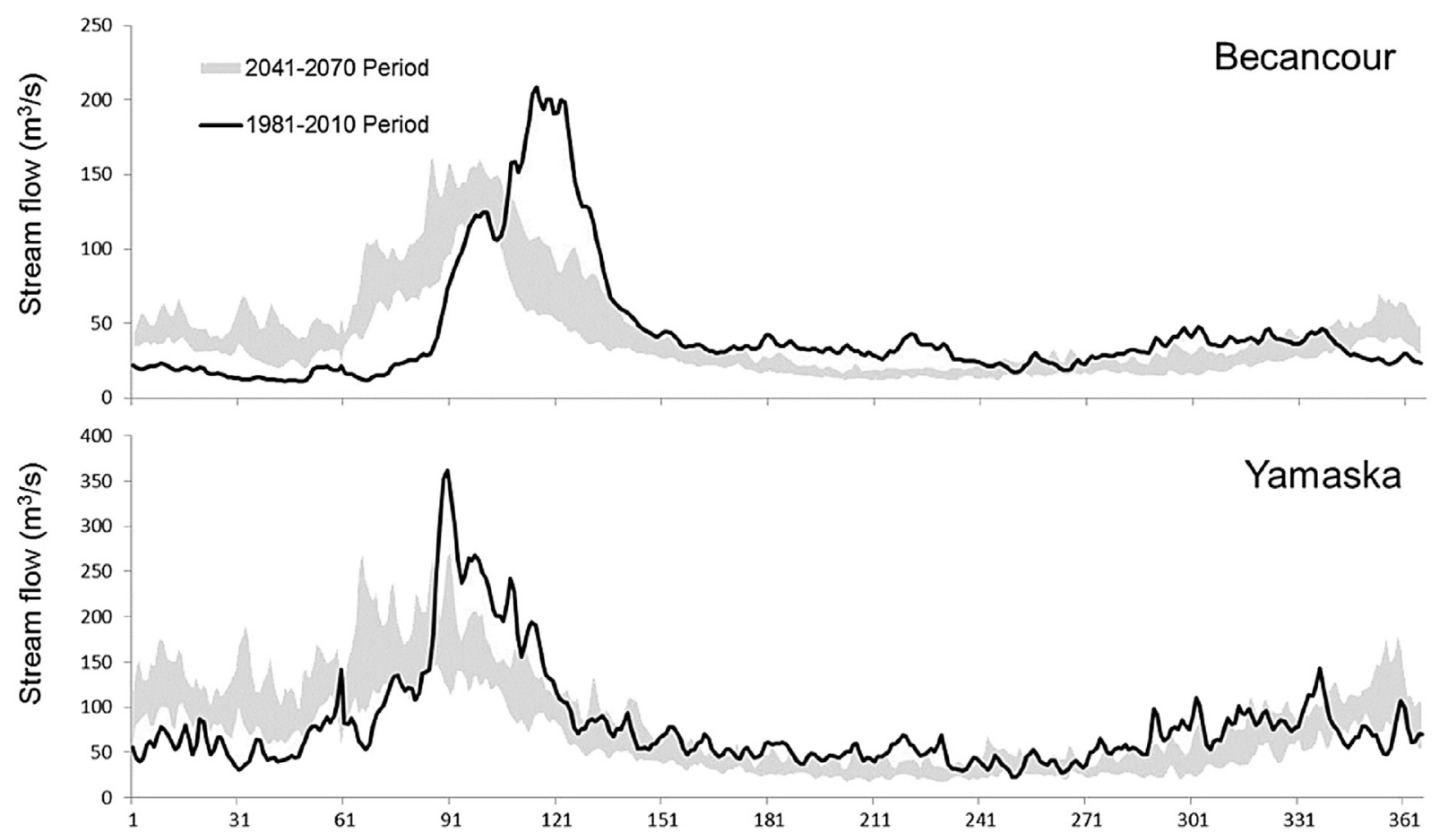

Fig. 3. Mean simulated hydrographs obtained for the reference period (1981-2010) and future climate scenarios (range of hydrographs over 2041-2070).

Table 4

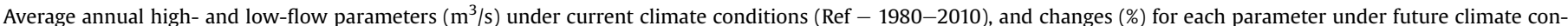
ditions (2040-2070).

\begin{tabular}{|c|c|c|c|c|c|c|c|c|c|c|c|c|}
\hline & \multicolumn{12}{|c|}{ Flow parameter $\left(\mathrm{m}^{3} / \mathrm{s}\right)$ and percentage of variation $(\%)$} \\
\hline & \multicolumn{6}{|c|}{ Becancour } & \multicolumn{6}{|c|}{ Yamaska } \\
\hline & \multicolumn{3}{|c|}{ High flows } & \multicolumn{3}{|c|}{ Low flows } & \multicolumn{3}{|c|}{ High flows } & \multicolumn{3}{|c|}{ Low flows } \\
\hline & $\mathrm{Q}_{2}$ & $\mathrm{Q}_{20}$ & $\mathrm{Q}_{100}$ & $\mathrm{Q}_{2-7}$ & $\mathrm{Q}_{10-7}$ & $\mathrm{Q}_{5-30}$ & $\mathrm{Q}_{2}$ & $\mathrm{Q}_{20}$ & $\mathrm{Q}_{100}$ & $\mathrm{Q}_{2-7}$ & $\mathrm{Q}_{10-7}$ & $\mathrm{Q}_{5-30}$ \\
\hline Ref & 352 & 557 & 673 & 7 & 5 & 6 & 825 & 1517 & 1954 & 9 & 7 & 11 \\
\hline acu & -9.1 & -6.3 & -5.1 & -13.5 & -20.1 & 3.4 & -5.0 & -16.3 & -20.7 & -28.2 & -38.9 & -14.4 \\
\hline adc & -13.4 & -5.1 & -1.3 & -7.9 & -17.0 & 11.3 & -6.4 & -5.3 & -4.9 & -27.6 & -46.8 & -21.7 \\
\hline adj & -14.4 & 2.6 & 10.7 & -21.4 & -32.5 & -8 & -16.2 & -19.3 & -20.6 & -39.0 & -52.2 & -28.7 \\
\hline adl & -12.3 & 6.2 & 15.0 & -3.3 & -19.5 & 11.6 & -1.8 & -0.8 & -0.4 & -30.5 & -51.3 & -25.7 \\
\hline aet & -14.4 & 8.6 & 20.0 & -19.2 & -27.5 & 0.8 & -13.0 & -16.7 & -18.2 & -38.3 & -48.2 & -25.7 \\
\hline aev & -11.8 & 11.1 & 22.4 & -7.6 & -21.9 & 8.1 & 3.2 & 3.7 & 3.8 & -33.3 & -49.4 & -22.8 \\
\hline afx & -11.7 & -14.4 & -15.4 & -5.3 & -11.5 & 13.4 & -6.5 & -17.7 & -22.0 & -24.0 & -36.1 & -11.6 \\
\hline agr & -14.5 & -2.7 & 2.8 & 1.9 & -4.5 & 23.0 & -13.1 & -13.1 & -13.1 & -22.3 & -42.2 & -15.7 \\
\hline agx & -7.4 & 12.8 & 22.5 & -7.7 & -18.8 & 5.8 & -1.5 & -8.2 & -11.0 & -24.9 & -44.4 & -15.0 \\
\hline aha & -1.0 & 15.6 & 23.4 & 1.3 & -3.7 & 24.2 & -0.8 & 3.0 & 4.6 & -17.6 & -30.4 & -0.2 \\
\hline
\end{tabular}

Also, and as reported in Table 4, these variations affect the values of the hydrological indicators both for the Becancour and Yamaska River watersheds, but with different trends. For the Becancour, the $\mathrm{Q}_{2}$ trend is downward for all climatic scenarios indicating a decrease between $1 \%$ and $14.5 \%$. However, for the $\mathrm{Q}_{20}$ and $\mathrm{Q}_{100}$, the simulated trend is less clear with variations ranging between $-14.4 \%$ and $15.6 \%$ and from $-15.4 \%$ to $23.4 \%$, respectively. Low-flow indicators show a downward trend for both $\mathrm{Q}_{2-7}$ and $\mathrm{Q}_{10}$ 7 with mainly negative values obtained for all scenarios, ranging from $-21.4 \%$ to $1.3 \%$ and from $-32.5 \%$ to $-3.7 \%$, respectively. The last low-flow indicator $\left(\mathrm{Q}_{5-30}\right)$ displays an increasing trend up to $24.2 \%$, with a single negative value of $-8 \%$.

While the Yamaska watershed is characterized by an overall downward trend for all indicators. The majority of high-flow indicators show negative trends ( 8 scenarios at least), whereas all low-flow indicators have negative variations. The values vary from $-16.2 \%$ to $3.2 \%$ for $Q_{2}$, from $-19.3 \%$ to $3.7 \%$ for $Q_{20}$, and from $-22 \%$ to $4.6 \%$ for $Q_{100}$. Similarly, the values of the low-flow indicators vary from $-39 \%$ to $-17.6 \%$ for $Q_{2-7}$, from $-52.2 \%$ to $-30.4 \%$ for $\mathrm{Q}_{5-30}$.

Similar decreasing trends for $\mathrm{Q}_{2}, \mathrm{Q}_{2-7}$ and $\mathrm{Q}_{10-7}$ were expected for both studied watersheds. Differences observed for $\mathrm{Q}_{20}, \mathrm{Q}_{100}$ and $\mathrm{Q}_{5-30}$ may be related to several parameters (all values of hydrological indicators are reported in Tables 5 and 6). On one hand, landscape conditions (i.e., slope, soil characteristics, Gravelius index and land cover - without loss of continuity not reported here) for the Becancour watershed differ from those of the Yamaska watershed, affecting spatial and temporal distributions of flows as 
Table 5

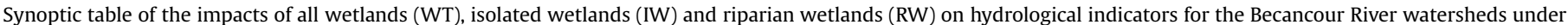
current climate conditions (Ref - 1980-2010) and future climate conditions (2040-2070).

\begin{tabular}{|c|c|c|c|c|c|c|c|c|c|c|c|c|}
\hline & & \multirow[t]{2}{*}{ Ref } & \multicolumn{10}{|c|}{ Hydrological indicators $\left(\mathrm{m}^{3} / \mathrm{s}\right)$ for the Becancour watershed } \\
\hline & & & acu & adc & adj & adl & aet & aev & $a f x$ & agr & $\operatorname{agx}$ & aha \\
\hline \multirow[t]{4}{*}{$\mathrm{Q}_{2}$} & WT & 352 & 320 & 305 & 301 & 309 & 301 & 310 & 311 & 301 & 326 & 348 \\
\hline & WW & - & 411 & 401 & 395 & 414 & 398 & 413 & 401 & 398 & 433 & 452 \\
\hline & IW & - & 335 & 319 & 315 & 323 & 316 & 325 & 326 & 313 & 343 & 364 \\
\hline & RW & - & 372 & 360 & 357 & 369 & 358 & 370 & 361 & 355 & 387 & 411 \\
\hline \multirow[t]{4}{*}{$\mathrm{Q}_{20}$} & WT & 557 & 522 & 529 & 571 & 591 & 605 & 619 & 477 & 542 & 628 & 644 \\
\hline & WW & - & 682 & 743 & 791 & 820 & 808 & 883 & 628 & 738 & 851 & 820 \\
\hline & IW & - & 566 & 577 & 626 & 647 & 667 & 687 & 517 & 592 & 684 & 686 \\
\hline & RW & - & 608 & 644 & 692 & 716 & 711 & 760 & 555 & 647 & 761 & 745 \\
\hline \multirow[t]{4}{*}{$Q_{100}$} & WT & 673 & 639 & 664 & 745 & 774 & 808 & 824 & 569 & 692 & 824 & 831 \\
\hline & WW & - & 842 & 959 & 1054 & 1088 & 1083 & 1210 & 757 & 954 & 1126 & 1049 \\
\hline & IW & - & 703 & 738 & 833 & 863 & 908 & 936 & 626 & 770 & 911 & 892 \\
\hline & RW & - & 745 & 819 & 911 & 943 & 945 & 1024 & 663 & 830 & 1007 & 954 \\
\hline \multirow[t]{4}{*}{$\mathrm{Q}_{2-7}$} & WT & 7 & 6 & 6 & 6 & 7 & 6 & 6 & 7 & 7 & 6 & 7 \\
\hline & WW & - & 3 & 3 & 3 & 3 & 3 & 3 & 4 & 4 & 3 & 4 \\
\hline & IW & - & 6 & 7 & 6 & 7 & 6 & 7 & 7 & 7 & 7 & 7 \\
\hline & RW & - & 3 & 4 & 3 & 4 & 3 & 3 & 4 & 4 & 4 & 4 \\
\hline \multirow[t]{4}{*}{$\mathrm{Q}_{10-7}$} & WT & 5 & 4 & 4 & 3 & 4 & 4 & 4 & 4 & 5 & 4 & 5 \\
\hline & WW & - & 2 & 2 & 1 & 2 & 1 & 2 & 2 & 2 & 2 & 2 \\
\hline & IW & - & 4 & 5 & 4 & 4 & 4 & 4 & 5 & 5 & 4 & 5 \\
\hline & RW & - & 2 & 2 & 1 & 2 & 2 & 2 & 2 & 2 & 2 & 2 \\
\hline \multirow[t]{4}{*}{$Q_{5-30}$} & WT & 6 & 6 & 7 & 6 & 7 & 6 & 6 & 7 & 7 & 6 & 7 \\
\hline & WW & - & 4 & 4 & 3 & 5 & 4 & 4 & 4 & 5 & 4 & 5 \\
\hline & IW & - & 7 & 7 & 6 & 7 & 6 & 7 & 7 & 8 & 7 & 8 \\
\hline & RW & - & 4 & 5 & 3 & 5 & 4 & 4 & 5 & 5 & 4 & 5 \\
\hline
\end{tabular}

Table 6

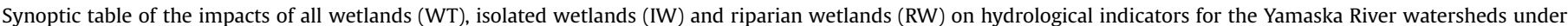
current climate conditions (Ref - 1980-2010) and future climate conditions (2040-2070).

\begin{tabular}{|c|c|c|c|c|c|c|c|c|c|c|c|c|}
\hline & & \multirow[t]{2}{*}{ Ref } & \multicolumn{10}{|c|}{ Hydrological indicators $\left(\mathrm{m}^{3} / \mathrm{s}\right)$ for the Yamaska watershed } \\
\hline & & & $\mathrm{acu}$ & adc & adj & adl & aet & aev & $a f x$ & agr & $\operatorname{agx}$ & aha \\
\hline \multirow[t]{4}{*}{$\mathrm{Q}_{2}$} & WT & 825 & 784 & 772 & 692 & 810 & 717 & 851 & 771 & 717 & 813 & 818 \\
\hline & WW & - & 828 & 798 & 732 & 855 & 758 & 899 & 815 & 758 & 862 & 863 \\
\hline & IW & - & 776 & 764 & 687 & 800 & 711 & 841 & 763 & 709 & 805 & 810 \\
\hline & RW & - & 831 & 818 & 733 & 860 & 759 & 899 & 818 & 761 & 864 & 866 \\
\hline \multirow[t]{4}{*}{$\mathrm{Q}_{20}$} & WT & 1517 & 1269 & 1436 & 1224 & 1505 & 1264 & 1573 & 1248 & 1319 & 1392 & 1563 \\
\hline & WW & - & 1344 & 1464 & 1296 & 1586 & 1332 & 1659 & 1319 & 1396 & 1485 & 1656 \\
\hline & IW & - & 1256 & 1418 & 1215 & 1488 & 1249 & 1551 & 1237 & 1302 & 1376 & 1545 \\
\hline & RW & - & 1349 & 1532 & 1298 & 1594 & 1339 & 1659 & 1323 & 1405 & 1489 & 1662 \\
\hline \multirow[t]{4}{*}{$\mathrm{Q}_{100}$} & WT & 1954 & 1550 & 1858 & 1551 & 1945 & 1598 & 2029 & 1524 & 1698 & 1740 & 2043 \\
\hline & WW & - & 1643 & 1883 & 1642 & 2049 & 1683 & 2138 & 1611 & 1799 & 1860 & 2169 \\
\hline & IW & - & 1534 & 1833 & 1539 & 1924 & 1577 & 1998 & 1511 & 1674 & 1717 & 2018 \\
\hline & RW & - & 1649 & 1987 & 1645 & 2058 & 1694 & 2138 & 1615 & 1811 & 1866 & 2178 \\
\hline \multirow[t]{4}{*}{$Q_{2-7}$} & WT & 9 & 6 & 7 & 5 & 6 & 6 & 6 & 7 & 7 & 7 & 7 \\
\hline & WW & - & 5 & 5 & 4 & 4 & 4 & 4 & 5 & 5 & 5 & 6 \\
\hline & IW & - & 6 & 7 & 6 & 6 & 6 & 6 & 7 & 7 & 7 & 7 \\
\hline & RW & - & 5 & 5 & 4 & 5 & 4 & 4 & 5 & 5 & 5 & 6 \\
\hline \multirow[t]{4}{*}{$\mathrm{Q}_{10-7}$} & WT & 7 & 4 & 4 & 3 & 3 & 4 & 4 & 4 & 4 & 4 & 5 \\
\hline & WW & - & 3 & 2 & 2 & 2 & 2 & 2 & 3 & 3 & 3 & 3 \\
\hline & IW & - & 4 & 4 & 3 & 4 & 4 & 4 & 4 & 4 & 4 & 5 \\
\hline & RW & - & 3 & 2 & 2 & 2 & 2 & 2 & 3 & 3 & 3 & 4 \\
\hline \multirow[t]{4}{*}{$\mathrm{Q}_{5-30}$} & WT & 11 & 9 & 9 & 8 & 8 & 8 & 8 & 10 & 9 & 9 & 11 \\
\hline & WW & - & 8 & 7 & 6 & 7 & 7 & 7 & 8 & 8 & 8 & 9 \\
\hline & IW & - & 9 & 9 & 8 & 8 & 8 & 9 & 10 & 9 & 9 & 11 \\
\hline & RW & - & 8 & 7 & 7 & 7 & 7 & 7 & 8 & 8 & 8 & 10 \\
\hline
\end{tabular}

introduced above. On other hand, meteorological characteristics for the future period vary slightly between the two watersheds. Based on Appendix C and Appendix D, it can be noted that, under changing climate conditions, temperatures are expected to increase by $3-4{ }^{\circ} \mathrm{C}$ for the Becancour and by $2-3{ }^{\circ} \mathrm{C}$ for the Yamaska, rainfalls are expected to increase by $18 \%-30 \%$ and $12 \%-23 \%$; while snow is expected to decrease by $31 \%-45 \%$ and $34 \%-50 \%$, respectively. In other words, these slight variations in precipitations and temperatures, as suggested by these first results (i.e., more variable flow regime for Becancour watershed and differences with respect to snow processes) coupled with landscape conditions may partially explain some of the differences found. However, while landscape conditions are considered time-invariant in our modelling approach, their impacts on watershed hydrology are constant in time and space. 


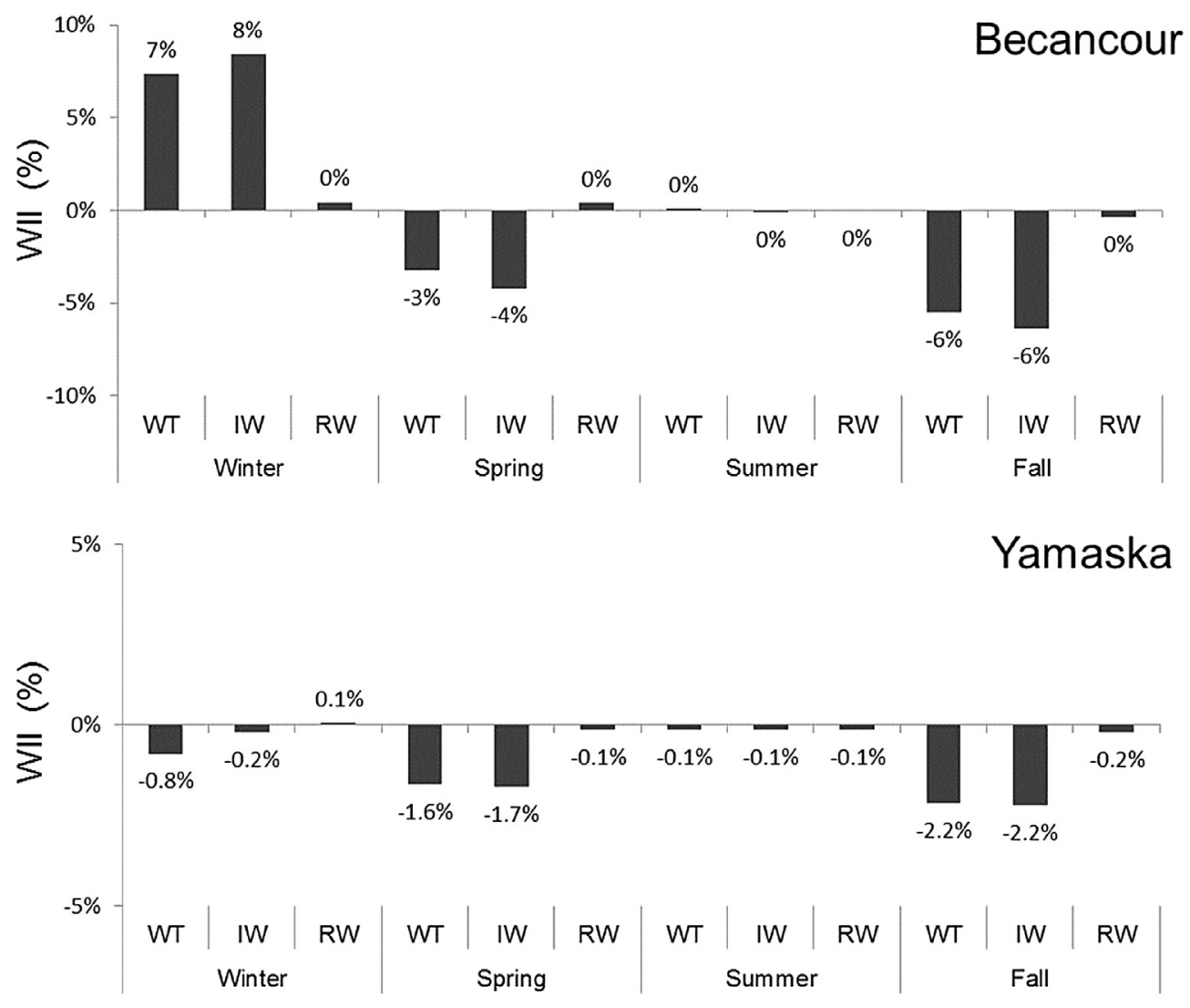

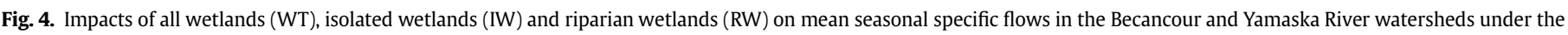
current period (1981-2010).

\subsection{Current impacts of wetlands on watershed hydrology}

As described by Fossey et al. (2016), the impact of wetlands on downgradient flows depends, to some extent, on upstream fluxes which are regulated by landscape conditions and climate. Therefore, for similar hydroclimatic conditions, the resulting impacts are governed by time-varying and space-varying fluxes. According to the hydrological modelling approach used, changes in upstream fluxes affect the hydrodynamics and hydrological functions of wetlands.

Impacts of wetlands on mean seasonal specific flows appear to be variable throughout the year (Fig. 4). Three distinct results can be highlighted: (i) during springs and falls, wetlands seem to participate to the decline of the mean seasonal flows, (ii) during summers, the impacts are almost null and (iii) during winters, while the Becancour wetlands induce a slight increase in the mean seasonal flow, for the Yamaska watershed, their presence appears to slightly decrease the mean seasonal flow. At these seasonal scales, RWs seem to have very limited effects. These findings are linked to similar IW and RW attributes (i.e., wetland area and drainage area) within the Yamaska watershed (Table 1).

As shown by the changes (\%) in the values of the hydrological indicators caused by the different types of wetlands (Fig. 5), at the interannual scale, characterized by more timely and more extreme hydrological events, results differ. For the Becancour watershed, the WT simulation ( $12 \%$ of the watershed area in wetlands) leads to a decrease in high flows of $18 \%$ for $\mathrm{Q}_{2}, 16 \%$ for $\mathrm{Q}_{20}$, and $14 \%$ for $\mathrm{Q}_{100}$; whereas the mere presence of IWs ( $8 \%$ of the watershed) leads to decreases of $16 \%, 13 \%$, and $12 \%$, respectively. Meanwhile, RWs ( $4 \%$ of the watershed) are responsible for a decrease of $7 \%, 7 \%$ and $6 \%$ for $\mathrm{Q}_{2}, \mathrm{Q}_{20}$, and $\mathrm{Q}_{100}$, respectively. For low flows, WT and IWs show a similar effect on both $\mathrm{Q}_{2-7}$ and $\mathrm{Q}_{10-7}$ with an increase of $75 \%$ and $67 \%$, respectively. For the $\mathrm{Q}_{5-30}$ indicator, WT leads to an increase of $50 \%$ while it is $75 \%$ for IWs. RWs seem to have not as strong as an impact, although substantial with an increase of $25 \%$ for $\mathrm{Q}_{2-7}$ and $0 \%$ for other indicators.

Some differences are observed for the Yamaska watershed. RWs seem to have no effect $\left(0 \%\right.$ of variation for $\left.\mathrm{Q}_{2}\right)$ or a slight negative effect (1\% increase) on the $\mathrm{Q}_{20}$ and $\mathrm{Q}_{100}$. This negative effect of RWs, described in previous work (Fossey et al., 2016), results from the modelling of RWs which accounts for their capacity to contribute to the river flow during high flow conditions, reversing the capacity of storing water and enhancing the high flow conditions. It underlines the time-varying issue of water exchange conditions between RWs, rivers, and adjacent uplands (Burt et al., 2002). Considering low flows, WT and IWs have the same impact with variation of $29 \%, 40 \%$ and $22 \%$ for $\mathrm{Q}_{2-7}, \mathrm{Q}_{10-7}$ and $\mathrm{Q}_{5-30}$, respectively. $\mathrm{RWs}$ have less impact with an increase of $14 \%$ for $\mathrm{Q}_{2-7}$ and $0 \%$ for other indicators.

Overall, at the event scale any type of wetlands plays a role in reducing peak flows (decreasing values of high-flow indicators) and sustaining low flows (increasing values of low-flow indicators). However, at the seasonal scale, wetlands generally reduce flows. These results demonstrate the damping effect of wetlands on watershed hydrology. Indeed, the presence of wetlands limits high variation between maximum and minimum flows. However, the cumulative effect of all wetlands (WT simulation) remains less than 

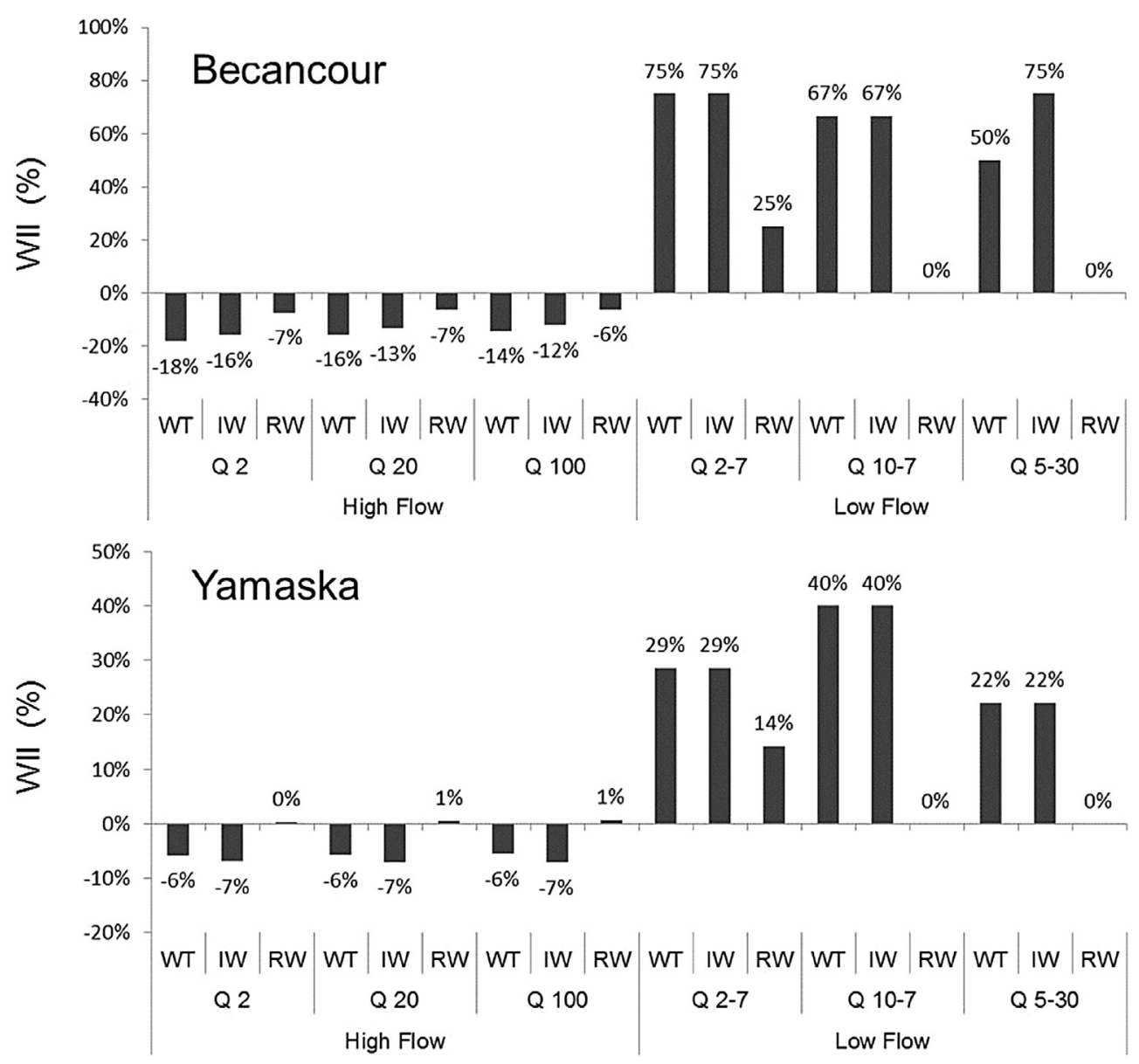

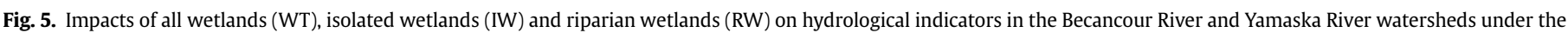
current conditions (1981-2010).

the sum of the individual effects of each typology (IWs and RWs) since the outflows of IWs are in some RHHUs routed through RWs. Moreover, for the Yamaska watershed, wetlands appear to have a constant impact regardless of the considered HIs. Whereas, for the Becancour watershed, the more the HIs are substantial $\left(Q_{2}\right.$ to $\left.Q_{100}\right)$ the less wetlands are efficient flow regulators. These differences in results illustrate the complexity of the water exchanges between IWs, RWs, and surrounding landscapes as described by Fossey et al. (2016).

\subsection{Evolution of the impacts of wetlands under changing climate conditions}

Under CC conditions and considering the current wetland distributions, watershed hydrology will change (Fig. 3 and Table 4). At the seasonal scale, the flow variation due to wetlands appears low compared to the expected changes due to CC. So, the assessment of their impacts will be modulated by the variation of hydrological indicators (Tables 5 and 6). Not accounting for wetlands induce variable changes under CC conditions depending on both the considered watershed and the hydrological indicator of interest.

For the Becancour watershed, not accounting for IWs (8\%) leads to increases of $1 \%-10 \%$ in the values of $\mathrm{Q}_{2}$. Meanwhile, for $\mathrm{Q}_{20}$ and $\mathrm{Q}_{100}$, the conservation of existing wetlands is not enough to maintain current flow conditions. Increases from $2.5 \%$ to $16 \%\left(\mathrm{Q}_{20}\right)$ and from $3 \%$ to $23.5 \%\left(Q_{100}\right)$ could be expected. Thenceforth, any losses would increase flows. Moreover, the loss of all wetlands (12\%) would increase the $Q_{20}$ value to that of the $Q_{100}$. For low flows, results show that the conservation of existing wetlands could maintain current values or induce a decrease ranging from $17 \%\left(\mathrm{Q}_{2}\right.$ 7) to $40 \%\left(Q_{10-7}\right)$ or even lead to an increase of $17 \%\left(Q_{5-30}\right)$. Similar results are obtained with the conservation of IWs.

For the Yamaska watershed, the effects of CC related to wetlands conservation/loss are not as strong. For high flow indicators, most climatic/wetland scenarios would not produce increases and wetland conservation should be enough to maintain the current hydrological regime. In most cases, decreases are observed; ranging from $1 \%$ to $16 \%\left(\mathrm{Q}_{2}\right)$, from $1 \%$ to $19 \%\left(\mathrm{Q}_{20}\right)$ and from $0.5 \%$ to $22 \%$ $\left(Q_{100}\right)$. It is noteworthy that in all scenarios, impacts of IWs are greater than the combined effect of IWs and RWs (i.e., WT scenario). As for the Becancour watershed, the total loss of wetlands (4\%) or the loss of IWs (2\%) would have similar impacts on these hydrological indicators. On the other end, the conservation of existing wetlands would not be enough to mitigate the expected decreases in low flows; ranging from $22 \%$ to $44 \%\left(\mathrm{Q}_{2-7}\right)$, from $29 \%$ to $57 \%\left(\mathrm{Q}_{10}\right.$ 7), and from $0 \%$ to $27 \%\left(Q_{5-30}\right)$.

To summarize, wetlands would keep their current role of flow regulators. Their presence would still lead to a decrease of high 
flows and an increase of low flows. However, their capacity to compensate for modifications due to climate change would be watershed-specific.

\section{Conclusion}

Wetlands are natural landscape features which contribute to the regulation of stream flows, reducing high flows and increasing low flows. The modifications in spatial and temporal distributions of meteorological patterns (rainfall, temperatures, snow) driven by CC conditions will affect the overall availability of water to flow through river networks. Within the Becancour River and the Yamaska River watersheds, these variations will lead to higher and earlier spring flows with shifts and decreases in future spring floods and lower summer and fall flows.

At the seasonal scale, the impacts of wetlands vary, but they contribute to a general decrease of mean seasonal flows. However, the results indicate that the impacts are relatively low when compared to the expected impacts of CC. Meanwhile, for high flow indicators, wetlands lead to a decrease in high flows between $18 \%$ and $14 \%$ and a decrease of $6 \%$, for the Becancour River and the Yamaska River, respectively. For low flow indicators, for the Becancour the increase ranges from $50 \%$ to $75 \%$ and for the Yamaska from $22 \%$ to $40 \%$.Under changing climate conditions, the conservation of wetlands for the Becancour watershed appears not sufficient to maintain current high flows $\left(\mathrm{Q}_{20}\right.$ and $\left.\mathrm{Q}_{100}\right)$ and, thus, compensate for the expected increase due to CC; for the Yamaska watershed, the results suggest that they would mitigate the decline caused by CC. On the other hand, regardless of the watershed, any loss would be harmful for low flows $\left(\mathrm{Q}_{2-7}, \mathrm{Q}_{10-7}\right.$ and $\left.\mathrm{Q}_{5-30}\right)$. Based on the studied CC conditions, the current state of wetlands should provide a relevant support for low flows while maintaining a major role for flood control. In some cases, loss of wetlands would increase $Q_{20}$ values to those of $Q_{100}$. However, different impacts induced by each typology of wetlands (IWs and RWs) reinforce the individualized impact that wetlands have according to their local landscape conditions making them more or less sensitive to expected perturbations induced by CC.

That being said, the results presented here may be viewed as optimistic considering the rate of wetland areas loss (approximately 11\% observed between 1984 and 2011) and their inherent vulnerability to climate change described in previous work (Fossey and Rousseau, 2016-40\% of wetlands could be affected in their hydrological functions by climate change on the Becancour watershed). The results argue that it is only through some wetland restoration and conservation effort, increasing their total area, that wetlands could mitigate/compensate the CC effects. Finally, they suggest that it is nearly impossible to systematically transpose the impact of a given type of wetlands to another watershed. Thenceforth, if conservation/restoration programs are needed to compensate partially or totally the expected effect of CC, they should be first assessed using a watershed-scale hydrological modelling framework.

\section{Acknowledgments}

This study was done as part of a collaborative research project (Outils d'analyses hydrologique, économique et spatiale des services écologiques procurés par les milieux humides des basses terres du Saint-Laurent: adaptations aux changements climatiques) between Université de Sherbrooke (Richard Fournier, principal investigator, Jérôme Théau), Centre Eau Terre Environnement, INRS (Alain N. Rousseau), Université Laval (Monique Poulin), and UQÀM (Jean-
Pierre Revéret). It was conducted within the framework of the Climate Change Action Plan 26 "Biodiversity" coordinated and funded by Ouranos, a Consortium on Regional Climatology and Adaptation to Climate Change (Robert Siron, biodiversity program coordinator). Supplemental funding came from the Discovery Grant program of the Natural Sciences and Engineering Research Council (NSERC) of Canada (Alain N. Rousseau, principal investigator). We would like to thank Stéphane Savary and Alain Royer of INRS-ETE for their technical support. Finally, we would like to thank the reviewers, and editors for their meaningful comments. They significantly helped us improve the overall quality of the paper.

\section{Appendix A}

Reference climate conditions of the study area, 1981-2010 Reference climate conditions of the study area (1981-2010) (observed data).

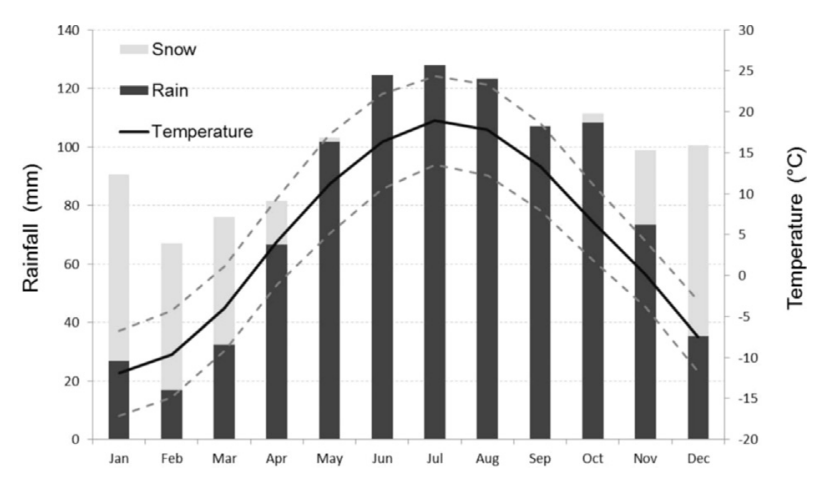

Climate graph for the mean future conditions of the study area (2040-2070) from simulated data.

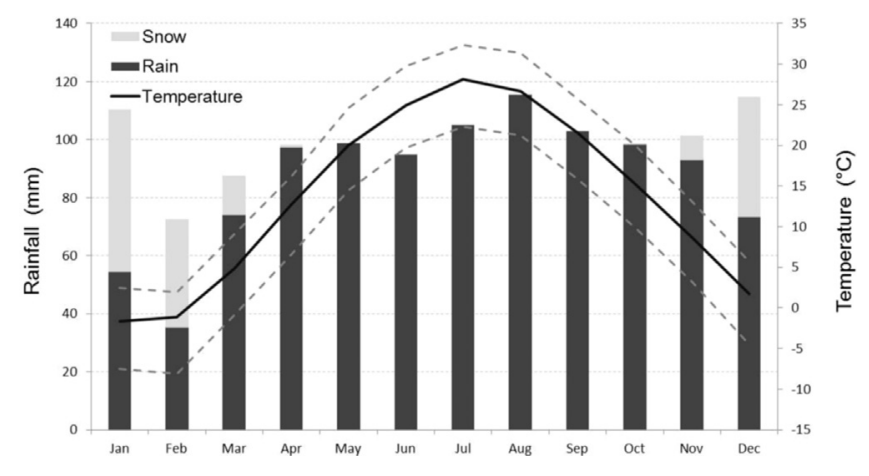

Appendix B 
Monthly climate statistics for the Becancour and the Yamaska watersheds for the 1981-2010 period.

\begin{tabular}{|c|c|c|c|c|c|c|c|}
\hline & \multirow[t]{2}{*}{ Month } & \multicolumn{3}{|c|}{ Temperatures $\left({ }^{\circ} \mathrm{C}\right)$} & \multicolumn{3}{|c|}{ Precipitations } \\
\hline & & Max & Min & Mean & Rain (mm) & Snow $(\mathrm{cm})$ & Total (mm) \\
\hline \multirow[t]{13}{*}{ Becancour River watershed } & January & -6.7 & -17 & -11.9 & 26.9 & 63.9 & 89.9 \\
\hline & February & -4.3 & -15 & -9.6 & 16.9 & 50.2 & 68.3 \\
\hline & March & 1.1 & -9.2 & -4.0 & 32.3 & 43.7 & 76.6 \\
\hline & April & 9.4 & -1.2 & 4.1 & 66.6 & 15.2 & 80.5 \\
\hline & May & 17.2 & 5.1 & 11.2 & 101.8 & 1.4 & 103.2 \\
\hline & June & 22.2 & 10.6 & 16.4 & 124.6 & 0 & 124.6 \\
\hline & July & 24.3 & 13.5 & 18.9 & 127.9 & 0 & 127.9 \\
\hline & August & 23.3 & 12.3 & 17.7 & 123.3 & 0 & 123.3 \\
\hline & September & 18.6 & 7.9 & 13.3 & 107.2 & 0 & 107.2 \\
\hline & October & 11.2 & 1.9 & 6.6 & 108.2 & 3.2 & 111.1 \\
\hline & November & 4.2 & -3.9 & 0.2 & 73.3 & 25.5 & 100.7 \\
\hline & December & -3.1 & -12 & -7.4 & 35.4 & 65.1 & 101.1 \\
\hline & Annual & 9.8 & -0.6 & 4.6 & 944.1 & 268 & 1214 \\
\hline \multirow[t]{13}{*}{ Yamaska River watershed } & January & -5.4 & -15.8 & -10.6 & 28.6 & 56 & 86 \\
\hline & February & -3.2 & -14.2 & -8.7 & 23.6 & 46.9 & 70.9 \\
\hline & March & 2.3 & -8.2 & -2.9 & 35 & 41.9 & 76.6 \\
\hline & April & 11 & 0.1 & 5.5 & 79.5 & 14.4 & 93.5 \\
\hline & May & 18.4 & 6.1 & 12.2 & 105.7 & 0.5 & 106.2 \\
\hline & June & 23.4 & 11.4 & 17.4 & 112.2 & 0 & 112.2 \\
\hline & July & 25.5 & 13.8 & 19.6 & 116.2 & 0 & 116.2 \\
\hline & August & 24.5 & 12.6 & 18.5 & 123.9 & 0 & 123.9 \\
\hline & September & 19.9 & 8.3 & 14.1 & 103.5 & 0 & 103.5 \\
\hline & October & 12.5 & 2.5 & 7.5 & 110.8 & 3 & 113.8 \\
\hline & November & 5.4 & -2.7 & 1.3 & 86.6 & 19.9 & 106.5 \\
\hline & December & -1.9 & -10.6 & -6.2 & 37.5 & 61.7 & 98 \\
\hline & Annual & 11 & 0.3 & 5.6 & 962.8 & 244.2 & 1207 \\
\hline
\end{tabular}

\section{Appendix C}

Monthly climate statistics (a) for the period the 1980-2010 and (b) for the 10 climate scenarios for the period 2040-2070 in the Becancour River watershed.

\begin{tabular}{|c|c|c|c|c|c|c|c|c|c|c|c|c|c|c|c|}
\hline \multirow[t]{2}{*}{ Period } & \multirow[t]{2}{*}{ Scenario } & \multirow[t]{2}{*}{ Climate parameter } & \multicolumn{12}{|c|}{ Mean monthly values } & \multirow[t]{2}{*}{ Mean annual values } \\
\hline & & & $\mathrm{J}$ & $\mathrm{F}$ & M & A & M & $\mathrm{J}$ & $\mathrm{J}$ & A & $\mathrm{S}$ & $\mathrm{O}$ & $\mathrm{N}$ & $\mathrm{D}$ & \\
\hline \multirow[t]{3}{*}{ 1980-2010 (Current Period) } & \multirow[t]{3}{*}{ Current } & $\mathrm{P}(\mathrm{mm})$ & 14.3 & 12.0 & 28.5 & 70.4 & 94.3 & 115.8 & 125.1 & 119.4 & 105.9 & 99.8 & 61.8 & 22.4 & 869.6 \\
\hline & & Snow $(\mathrm{cm})$ & 104.3 & 75.9 & 54.8 & 13.7 & 0.9 & 0 & 0 & 0 & 0.2 & 3.9 & 35.9 & 98.6 & 388.3 \\
\hline & & $\mathrm{T}\left({ }^{\circ} \mathrm{C}\right)$ & -12.8 & -10.8 & -4.7 & 3.2 & 10.8 & 15.7 & 18.3 & 16.8 & 11.8 & 5.6 & -1.2 & -9.2 & 3.6 \\
\hline \multirow[t]{30}{*}{ 2040-2070 (Climate scenarios) } & \multirow[t]{3}{*}{ acu } & $\mathrm{P}(\mathrm{mm})$ & 41.2 & 27.8 & 70.0 & 88.5 & 112.2 & 119.0 & 99.4 & 127.3 & 107.2 & 100.8 & 86.8 & 50.0 & 1030.2 \\
\hline & & Snow $(\mathrm{cm})$ & 71.8 & 40.6 & 28.0 & 1.5 & 0.0 & 0.0 & 0.0 & 0.0 & 0.0 & 0.7 & 16.7 & 64.5 & 223.8 \\
\hline & & $\mathrm{T}\left({ }^{\circ} \mathrm{C}\right)$ & -7.8 & -6.7 & -0.2 & 7.4 & 14.3 & 19.2 & 22.4 & 20.8 & 15.2 & 9.1 & 2.5 & -4.5 & 7.7 \\
\hline & \multirow[t]{3}{*}{ adc } & $\mathrm{P}(\mathrm{mm})$ & 51.7 & 29.7 & 74.2 & 99.8 & 104.2 & 101.2 & 122.1 & 138.4 & 109.2 & 114.0 & 75.1 & 67.5 & 1087.1 \\
\hline & & Snow $(\mathrm{cm})$ & 75.1 & 56.5 & 18.2 & 2.2 & 0.0 & 0.0 & 0.0 & 0.0 & 0.0 & 0.5 & 13.3 & 51.1 & 216.9 \\
\hline & & $\mathrm{T}\left({ }^{\circ} \mathrm{C}\right)$ & -6.8 & -5.9 & -1.0 & 6.7 & 14.8 & 19.2 & 21.8 & 20.7 & 15.9 & 9.9 & 2.5 & -3.8 & 7.8 \\
\hline & \multirow[t]{3}{*}{ adj } & $\mathrm{P}(\mathrm{mm})$ & 39.6 & 27.8 & 52.9 & 82.3 & 103.7 & 107.7 & 113.2 & 124.5 & 118.5 & 94.8 & 88.4 & 55.1 & 1008.4 \\
\hline & & Snow $(\mathrm{cm})$ & 79.7 & 41.1 & 25.4 & 2.1 & 0.0 & 0.0 & 0.0 & 0.0 & 0.0 & 0.4 & 15.7 & 73.3 & 237.7 \\
\hline & & $\mathrm{T}\left({ }^{\circ} \mathrm{C}\right)$ & -8.3 & -7.0 & -0.7 & 7.2 & 14.4 & 19.5 & 22.8 & 21.3 & 15.6 & 9.0 & 2.7 & -4.9 & 7.6 \\
\hline & \multirow[t]{3}{*}{ adl } & $\mathrm{P}(\mathrm{mm})$ & 62.5 & 36.4 & 74.5 & 85.3 & 116.7 & 103.6 & 113.3 & 112.9 & 126.2 & 107.4 & 76.6 & 76.7 & 1092.1 \\
\hline & & Snow $(\mathrm{cm})$ & 69.4 & 48.3 & 23.5 & 3.3 & 0.0 & 0.0 & 0.0 & 0.0 & 0.0 & 0.6 & 15.0 & 44.4 & 204.6 \\
\hline & & $\mathrm{T}\left({ }^{\circ} \mathrm{C}\right)$ & -6.5 & -5.9 & -1.2 & 6.7 & 14.7 & 19.0 & 22.4 & 21.1 & 15.8 & 9.7 & 2.5 & -3.4 & 7.9 \\
\hline & \multirow[t]{3}{*}{ aet } & $\mathrm{P}(\mathrm{mm})$ & 42.8 & 25.6 & 56.6 & 85.4 & 97.6 & 109.8 & 110.1 & 125.5 & 114.8 & 93.8 & 100.7 & 67.9 & 1030.5 \\
\hline & & Snow $(\mathrm{cm})$ & 69.6 & 41.0 & 20.1 & 2.4 & 0.0 & 0.0 & 0.0 & 0.0 & 0.0 & 0.4 & 11.7 & 62.1 & 207.3 \\
\hline & & $\mathrm{T}\left({ }^{\circ} \mathrm{C}\right)$ & -8.1 & -7.1 & -0.6 & 7.1 & 14.6 & 19.4 & 22.8 & 21.2 & 15.4 & 9.2 & 3.3 & -4.2 & 7.8 \\
\hline & \multirow[t]{3}{*}{ aev } & $\mathrm{P}(\mathrm{mm})$ & 56.3 & 34.7 & 76.5 & 98.9 & 114.4 & 97.9 & 105.1 & 127.6 & 121.3 & 111.5 & 89.0 & 79.1 & 1112.3 \\
\hline & & Snow $(\mathrm{cm})$ & 71.6 & 56.0 & 20.0 & 2.4 & 0.0 & 0.0 & 0.0 & 0.0 & 0.0 & 1.0 & 13.4 & 42.2 & 206.6 \\
\hline & & $\mathrm{T}\left({ }^{\circ} \mathrm{C}\right)$ & -6.3 & -5.8 & -0.9 & 6.7 & 14.5 & 19.1 & 22.3 & 21.1 & 16.0 & 9.8 & 3.0 & -3.1 & 8.0 \\
\hline & \multirow[t]{3}{*}{ afx } & $\mathrm{P}(\mathrm{mm})$ & 42.1 & 28.4 & 67.7 & 87.1 & 109.9 & 120.8 & 107.2 & 135.0 & 104.9 & 102.3 & 91.4 & 57.3 & 1054.0 \\
\hline & & Snow $(\mathrm{cm})$ & 72.7 & 39.5 & 27.3 & 1.6 & 0.0 & 0.0 & 0.0 & 0.0 & 0.0 & 0.6 & 14.3 & 58.5 & 214.4 \\
\hline & & $\mathrm{T}\left({ }^{\circ} \mathrm{C}\right)$ & -7.8 & -6.8 & -0.3 & 7.7 & 14.1 & 19.1 & 22.5 & 20.9 & 15.2 & 9.2 & 2.8 & -4.1 & 7.7 \\
\hline & \multirow[t]{3}{*}{ agr } & $\mathrm{P}(\mathrm{mm})$ & 53.5 & 30.7 & 72.2 & 99.6 & 97.9 & 99.0 & 127.9 & 146.0 & 109.3 & 111.8 & 78.1 & 76.0 & 1102.1 \\
\hline & & Snow $(\mathrm{cm})$ & 72.6 & 56.6 & 18.6 & 1.9 & 0.0 & 0.0 & 0.0 & 0.0 & 0.0 & 0.4 & 10.5 & 44.6 & 205.2 \\
\hline & & $\mathrm{T}\left({ }^{\circ} \mathrm{C}\right)$ & -6.7 & -5.9 & -1.1 & 6.9 & 14.5 & 19.2 & 21.9 & 20.7 & 15.9 & 9.9 & 2.9 & -3.4 & 7.9 \\
\hline & \multirow[t]{3}{*}{$\operatorname{agx}$} & $\mathrm{P}(\mathrm{mm})$ & 42.6 & 28.6 & 59.3 & 82.1 & 124.5 & 100.8 & 106.8 & 118.6 & 123.8 & 102.2 & 100.1 & 59.6 & 1049.0 \\
\hline & & Snow $(\mathrm{cm})$ & 84.0 & 56.0 & 19.6 & 2.9 & 0.0 & 0.0 & 0.0 & 0.0 & 0.0 & 1.0 & 10.9 & 57.8 & 232.3 \\
\hline & & $\mathrm{T}\left({ }^{\circ} \mathrm{C}\right)$ & -8.1 & -8.6 & -1.9 & 5.6 & 13.9 & 18.7 & 21.8 & 20.7 & 15.4 & 9.3 & 3.3 & -4.8 & 7.1 \\
\hline & \multirow[t]{3}{*}{ aha } & $\mathrm{P}(\mathrm{mm})$ & 39.3 & 25.9 & 56.3 & 82.4 & 106.8 & 93.9 & 111.3 & 152.1 & 135.9 & 102.9 & 78.0 & 63.7 & 1048.5 \\
\hline & & Snow $(\mathrm{cm})$ & 89.9 & 57.8 & 26.4 & 2.7 & 0.2 & 0.0 & 0.0 & 0.0 & 0.0 & 1.1 & 11.7 & 66.7 & 256.5 \\
\hline & & $\mathrm{T}\left({ }^{\circ} \mathrm{C}\right)$ & -8.3 & -8.1 & 2.0 & 5.8 & 14.0 & 18.7 & 21.6 & 20.5 & 15.2 & 9.2 & 3.0 & -4.9 & 7.0 \\
\hline
\end{tabular}




\section{Appendix D}

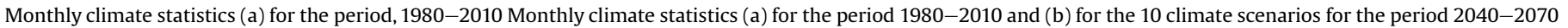
in the Yamaska River watershed

\begin{tabular}{|c|c|c|c|c|c|c|c|c|c|c|c|c|c|c|c|}
\hline \multirow[t]{2}{*}{ Period } & \multirow[t]{2}{*}{ Scenario } & \multirow[t]{2}{*}{ Climate parameter } & \multicolumn{12}{|c|}{ Mean monthly values } & \multirow[t]{2}{*}{ Mean annual values } \\
\hline & & & $\mathrm{J}$ & $\mathrm{F}$ & M & A & M & $\mathrm{J}$ & $\mathrm{J}$ & A & $S$ & 0 & $\mathrm{~N}$ & $\mathrm{D}$ & \\
\hline \multirow[t]{3}{*}{ 1980-2010 (Current Period) } & \multirow[t]{3}{*}{ Current } & $\mathrm{P}(\mathrm{mm})$ & 22.1 & 19.3 & 37.2 & 79.1 & 93.1 & 101.2 & 110.1 & 116.1 & 102.7 & 90.8 & 76.1 & 29.4 & 877.1 \\
\hline & & Snow $(\mathrm{cm})$ & 87.8 & 60.2 & 39.3 & 6.6 & 0.2 & 0 & 0 & 0 & 0.1 & 1.5 & 23.3 & 69.7 & 288.5 \\
\hline & & $\mathrm{T}\left({ }^{\circ} \mathrm{C}\right)$ & -10.7 & -8.7 & -2.9 & 5.4 & 12.5 & 17.3 & 19.8 & 18.6 & 13.8 & 7.4 & 0.9 & -6.8 & 5.5 \\
\hline \multirow[t]{30}{*}{ 2040-2070 (Climate scenarios) } & \multirow[t]{3}{*}{ acu } & $P(\mathrm{~mm})$ & 49.0 & 30.6 & 81.7 & 91.1 & 100.0 & 101.6 & 99.5 & 122.9 & 92.0 & 97.6 & 95.6 & 61.7 & 1023.4 \\
\hline & & Snow $(\mathrm{cm})$ & 56.1 & 31.6 & 18.0 & 0.2 & 0.0 & 0.0 & 0.0 & 0.0 & 0.0 & 0.3 & 10.8 & 49.4 & 166.5 \\
\hline & & $\mathrm{T}\left({ }^{\circ} \mathrm{C}\right)$ & -7.0 & -5.9 & 0.4 & 8.5 & 14.8 & 19.7 & 23.2 & 21.6 & 16.3 & 10.2 & 3.2 & -4.2 & 8.4 \\
\hline & \multirow[t]{3}{*}{ adc } & $\mathrm{P}(\mathrm{mm})$ & 55.3 & 38.1 & 78.1 & 111.3 & 98.3 & 91.1 & 112.4 & 118.6 & 99.8 & 109.5 & 83.3 & 75.3 & 1071.2 \\
\hline & & Snow $(\mathrm{cm})$ & 55.7 & 42.0 & 9.8 & 1.2 & 0.0 & 0.0 & 0.0 & 0.0 & 0.0 & 0.5 & 9.1 & 37.8 & 156.1 \\
\hline & & $\mathrm{T}\left({ }^{\circ} \mathrm{C}\right)$ & -6.1 & -5.4 & -0.1 & 7.8 & 15.6 & 20.3 & 22.9 & 21.6 & 17.2 & 10.6 & 3.2 & -2.7 & 8.7 \\
\hline & \multirow[t]{3}{*}{ adj } & $\mathrm{P}(\mathrm{mm})$ & 46.1 & 30.7 & 57.8 & 89.4 & 93.2 & 99.9 & 112.5 & 104.0 & 107.0 & 87.5 & 93.6 & 62.7 & 984.3 \\
\hline & & Snow $(\mathrm{cm})$ & 58.2 & 31.9 & 14.9 & 1.0 & 0.0 & 0.0 & 0.0 & 0.0 & 0.0 & 0.2 & 10.7 & 58.4 & 175.2 \\
\hline & & $\mathrm{T}\left({ }^{\circ} \mathrm{C}\right)$ & -7.5 & -6.3 & 0.2 & 8.5 & 14.8 & 19.9 & 23.6 & 22.0 & 16.6 & 10.1 & 3.5 & -4.6 & 8.4 \\
\hline & \multirow[t]{3}{*}{ adl } & $\mathrm{P}(\mathrm{mm})$ & 68.6 & 42.1 & 84.5 & 99.9 & 108.1 & 101.1 & 98.4 & 94.0 & 108.6 & 96.5 & 83.2 & 82.8 & 1067.9 \\
\hline & & Snow $(\mathrm{cm})$ & 48.8 & 36.3 & 13.8 & 1.9 & 0.0 & 0.0 & 0.0 & 0.0 & 0.0 & 0.3 & 8.9 & 32.0 & 142.0 \\
\hline & & $\mathrm{T}\left({ }^{\circ} \mathrm{C}\right)$ & -5.8 & -5.3 & -0.3 & 7.5 & 15.7 & 20.0 & 23.5 & 22.0 & 17.1 & 10.6 & 3.5 & -2.2 & 8.9 \\
\hline & \multirow[t]{3}{*}{ aet } & $\mathrm{P}(\mathrm{mm})$ & 52.0 & 29.4 & 61.8 & 93.6 & 88.4 & 89.4 & 101.4 & 115.5 & 103.2 & 89.5 & 105.3 & 78.2 & 1007.7 \\
\hline & & Snow $(\mathrm{cm})$ & 50.6 & 29.7 & 12.1 & 1.0 & 0.0 & 0.0 & 0.0 & 0.0 & 0.0 & 0.1 & 7.2 & 42.9 & 143.7 \\
\hline & & $\mathrm{T}\left({ }^{\circ} \mathrm{C}\right)$ & -7.4 & -6.4 & 0.4 & 8.7 & 14.9 & 19.9 & 23.7 & 22.0 & 16.6 & 10.2 & 4.0 & -3.4 & 8.6 \\
\hline & \multirow[t]{3}{*}{$\mathrm{aev}$} & $\mathrm{P}(\mathrm{mm})$ & 63.9 & 44.3 & 90.1 & 108.5 & 99.3 & 90.1 & 93.1 & 105.6 & 109.7 & 101.4 & 93.4 & 85.3 & 1084.7 \\
\hline & & Snow $(\mathrm{cm})$ & 51.3 & 39.7 & 12.2 & 0.8 & 0.0 & 0.0 & 0.0 & 0.0 & 0.0 & 0.4 & 8.6 & 29.6 & 142.6 \\
\hline & & $\mathrm{T}\left({ }^{\circ} \mathrm{C}\right)$ & -5.6 & -5.2 & -0.1 & 7.6 & 15.5 & 20.1 & 23.4 & 21.9 & 17.2 & 10.5 & 3.8 & -1.9 & 8.9 \\
\hline & \multirow[t]{3}{*}{ afx } & $\mathrm{P}(\mathrm{mm})$ & 50.3 & 31.5 & 79.9 & 94.0 & 97.2 & 100.8 & 104.7 & 123.7 & 92.6 & 96.8 & 97.6 & 68.6 & 1037.7 \\
\hline & & Snow $(\mathrm{cm})$ & 56.0 & 31.0 & 17.4 & 0.2 & 0.0 & 0.0 & 0.0 & 0.0 & 0.0 & 0.3 & 9.4 & 42.3 & 156.7 \\
\hline & & $\mathrm{T}\left({ }^{\circ} \mathrm{C}\right)$ & -7.0 & -6.0 & 0.2 & 9.1 & 14.5 & 19.7 & 23.2 & 21.6 & 16.3 & 10.2 & 3.5 & -3.5 & 8.5 \\
\hline & \multirow[t]{3}{*}{ agr } & $\mathrm{P}(\mathrm{mm})$ & 57.1 & 40.0 & 77.7 & 110.8 & 89.5 & 93.1 & 110.8 & 121.5 & 99.1 & 106.5 & 86.2 & 82.0 & 1074.3 \\
\hline & & Snow $(\mathrm{cm})$ & 53.0 & 40.5 & 9.9 & 0.7 & 0.0 & 0.0 & 0.0 & 0.0 & 0.0 & 0.3 & 7.7 & 31.1 & 143.2 \\
\hline & & $\mathrm{T}\left({ }^{\circ} \mathrm{C}\right)$ & -5.9 & -5.4 & -0.2 & 8.4 & 15.2 & 20.3 & 22.9 & 21.6 & 17.2 & 10.7 & 3.6 & -2.1 & 8.9 \\
\hline & \multirow[t]{3}{*}{$\operatorname{agx}$} & $\mathrm{P}(\mathrm{mm})$ & 56.1 & 34.3 & 62.3 & 90.0 & 112.0 & 93.6 & 107.0 & 112.0 & 100.3 & 99.3 & 103.8 & 66.5 & 1037.2 \\
\hline & & Snow $(\mathrm{cm})$ & 60.8 & 42.7 & 12.6 & 1.5 & 0.0 & 0.0 & 0.0 & 0.0 & 0.0 & 0.3 & 7.2 & 42.4 & 167.5 \\
\hline & & $\mathrm{T}\left({ }^{\circ} \mathrm{C}\right)$ & -7.0 & -8.1 & -0.6 & 6.6 & 14.8 & 19.7 & 22.6 & 21.4 & 16.1 & 9.9 & 4.0 & -3.9 & 8.0 \\
\hline & \multirow[t]{3}{*}{ aha } & $\mathrm{P}(\mathrm{mm})$ & 44.6 & 31.4 & 64.9 & 84.1 & 100.2 & 87.3 & 111.1 & 138.0 & 117.1 & 99.0 & 86.2 & 69.7 & 1033.5 \\
\hline & & Snow $(\mathrm{cm})$ & 69.9 & 47.5 & 17.0 & 0.9 & 0.0 & 0.0 & 0.0 & 0.0 & 0.0 & 0.5 & 6.5 & 47.7 & 190.1 \\
\hline & & $\mathrm{T}\left({ }^{\circ} \mathrm{C}\right)$ & -7.5 & -7.8 & -0.9 & 6.7 & 14.8 & 19.7 & 22.3 & 21.2 & 15.9 & 9.9 & 3.8 & -4.1 & 7.8 \\
\hline
\end{tabular}

\section{References}

Badeck, F.-W., Bondeau, A., Böttcher, K., Doktor, D., Lucht, W., Schaber, J., Sitch, S. 2004. Responses of spring phenology to climate change. New Phytol. 162 (2), 295-309.

Beaulieu, J. Murray, S., Villeneuve, C. 2012. Cartographie détaillée des milieux humides du territoire du centre du Québec - rapport de synthèse. Canards Illimités bureau du Québec et le ministère du Développement durable, de l'Environnement et des parcs. Québec, p. 44.

Bouda, M., Rousseau, A.N., Gumiere, S.J., Gagnon, P., Konan, B., Moussa, R., 2014. Implementation of an automatic calibration procedure for HYDROTEL based on prior OAT sensitivity and complementary identifiability analysis. Hydrol. Process. 28 (12), 3947-3961.

Bouda, M., Rousseau, A.N., Konan, B., Gagnon, P., Gumiere, S.J., 2012. Case study: Bayesian uncertainty analysis of the distributed hydrological model HYDROTEL. J. Hydrol. Eng. 17 (9), 1021-1032.

Boyer, C., Chaumont, D., Chartier, I., Roy, A.G., 2010. Impact of climate change on the hydrology of St. Lawrence tributaries. J. Hydrol. 384 (1-2), 65-83.

Brinson, M.M., 1993. Changes in the functioning of wetlands along environmental gradients. Wetlands $13,65-74$.

Brinson, M.M., 2009. The United States HGM (hydrogeomorphic) approach. In: The Wetlands Handbook, Chapter 22. Wilwy-Blackwell, Oxford, pp. 486-512.

Burt, T.P., Bates, P.D., Stewart, M.D., Claxton, A.J., Anderson, M.J., Price, D.A., 2002 Water table fluctuation within the floodplain of the river Severn, England. J. Hydrol. 262, 1-20.

Caya, D., Laprise, R., 1999. A semi-implicit semi-lagrangian regional climate model. Can. RCM. Mon. Weather Rev, 127 (3), 341-362.

de Elia, R., Côté, H., 2010. Climate and climate change sensitivity to model configuration in the Canadian RCM over North America. Meteorol. Zeitschrift 19 (4), $325-339$.

Erwin, K., 2009. Wetlands and global climate change: the role of wetland restoration in a changing world. Wetl. Ecol. Manag. 17 (1), 71-84.

Evenson, G.R., Golden, H.E., Lane, C.R., D'Amico, E., 2015. Geographically isolated wetlands and watershed hydrology: a modified model analysis. J. Hydrol. 529 (Part 1), 240-256.

Flato, G.M., Boer, G.J., 2001. Warming asymmetry in climate change simulations Geophys. Res. Lett. 28, 195-198.

Flato, G.M., Boer, G.J., Lee, W.G., McFarlane, N.A., Ramsden, D., Reader, M.C., Weaver, A.J., 2000. The Canadian center for climate modeling and analysis global coupled model and its climate. Clim. Dyn. 16, 451-467.

Fortin, J-P., Turcotte, R., Massicotte, S., Moussa, R., Fitzback, J, Villeneuve, J. 2001. Distributed watershed model compatible with remote sensing and GIS data, Part I: Description of the model. J. Hydrol. Eng. 6 (2), 91-99.

Fossey, M., Rousseau, A.N., 2016. Assessing the long-term hydrological services provided by wetlands under changing climate conditions: a case study approach of a Canadian watershed. J. Hydrol. http://dx.doi.org/10.1016 j.jhydrol.2016.08.032.

Fossey, M., Rousseau, A.N., Bensalma, F., Savary, S., Royer, A., 2015. Integrating isolated and riparian wetland modules in the PHYSITEL/HYDROTEL modelling platform: model performance and diagnosis. Hydrol. Process. 29, 4683-4702.

Fossey, M., Rousseau, A.N., Savary, S., 2016. Assessment of the impact of spatiotemporal attributes of wetlands on stream flows using a hydrological modelling framework: a theoretical case study of a watershed under temperate climatic conditions. Hydrol. Process. 30, 1768-1781.

Fu, B., Pollino, C.A., Cuddy, S.M., Andrews, F., 2015. Assessing climate change impacts on wetlands in a flow regulated catchment: a case study in the Macquarie Marshes, Australia. J. Environ. Manag. 157, 127-138.

Golden, H.E., Sander, H.A., Lane, C.R., Zhao, C., Price, K., D'Amico, E., Christensen, J.R 2015. Relative effects of geographically isolated wetlands on streamflows: watershed-scale analysis. Ecohydrology 9, 21-38.

Hartigan, J.A., Wong, M.A., 1979. A k-means clustering algorithm. Appl. Stat. 28, $100-108$.

Hebb, A.J., Mortsch, L.D., Deadman, P.J., Cabrera, A.R., 2013. Modeling wetland vegetation community response to water-level change at Long Point, Ontario. J. Gt. Lakes. Res. 39 (2), 191-200.

Jobin, B., Beaulieu, J., Grenier, M., Bélanger, L., Maisonneuve, C., Bordage, D., Filion, B., 2004. Les paysages agricoles du Québec méridional. Le. Nat. Can. 128 
(2), 92-98

Joly, M., Primeau, S., Sager, M., Bazoge, A., 2008. Guide d'élaboration d'un plan de conservation des milieux humides. Première édition, Québec, ministère du Développement durable, de l'Environnement et des Parcs, Direction du patrimoine écologique et des parcs, p. 68.

Jungclaus, J.H., Botzet, M., Haak, H., Keenlyside, N., Luo, J.J., Latif, M., Marotzke, J., Mikolajewicz, U., Roeckner, E., 2006. Ocean circulation and tropical variability in the AOGCM ECHAM5/MPI-OM. J. Clim. 19 (16), 3952-3972.

Li, T., Ducruc, J.-P., 1999. Les provinces naturelles. Niveau I du cadre écologique de référence du Québec, p. 90.

Liu, Y., Yang, W., Wang, X., 2008. Development of a SWAT extension module to simulate riparian wetland hydrologic processes at a watershed scale. Hydrol. Process. 22 (16), 2901-2915.

Mackey, B.G., McKenney, D.W., Yang, Y.Q., McMahon, J.P., Hutchinson, M.F., 1996 Site regions revisited : a climatic analysis of Hills'site regions for the Province of Ontario using a parametric method. Can. J. For. Res. 26, 333-354.

Martinez-Martinez, E., Nejadhashemi, A.P., Woznicki, S.A., Love, B.J., 2014. Modeling the hydrological significance of wetland restoration scenarios. J. Environ. Manag. 133 (0), 121-134.

McKenney, D.W., 1998. Classification climatique du Québec (travaux inédits ; cf Mackey et al., 1996).

MDDELCC, 2014. Ministère du Développement durable, de l'Environnement et de la Lutte contre les changements climatiques. Données du Programme de surveillance du climat, Direction du suivi de l'état de l'environnement, Québec.

Moriasi, D.N., Arnold, J.G., Van Liew, M.W., Bingner, R.L., Harmel, R.D., Veith, T.L. 2007. Model evaluation guidelines for systematic quantification of accuracy in watershed simulations. Am. Soc. Agric. Biol. Eng. 50 (3), 885-900.

Music, B., Caya, D., 2007. Evaluation of the hydrological cycle over the Mississipp river basin as simulated by the Canadian regional climate model (CRCM) J. Hydrometeorol. 8 (5), 969-988.

Nakicenvoic, N., Davidson, O., Davis, G., Grübler, A., Kram, T., Lebre La Rovera, E. Metz, B., Morita, T., Pepper, W., Pitcher, H., Sankovski, A., Shukla, P., Swart, R. Watson, R., Dadi, Z., 2000. Special Report on Emissions Scenarios. A Specia Report of Working Group III of the Intergovernmental Panel on Climate Change. Cambridge University Press, Cambridge, p. 599.

Nash, J.E., Sutcliffe, J.V., 1970. River flow forecasting through conceptual models part I-A : discussion of principles. J. Hydrol. 10, 282-290.

Nilsson, K.A., Rains, M.C., Lewis, D.B., Trout, K.E., 2013. Hydrologic characterization of 56 geographically isolated wetlands in west-central Florida using a probabilistic method. Wetl. Ecol. Manag. 21, 1-14.

Noël, P., Rousseau, A.N., Paniconi, C., Nadeau, D.F., 2014. An algorithm for delineating and extracting hillslopes and hillslope width functions from gridded elevation data. J. Hydrol. Eng. 19 (2), 366-374. http://dx.doi.org/10.1061/(ASCE) HE.1943-5584.0000783.

Ogawa, H., Male, J.W., 1986. Simulating the flood mitigation role of wetlands. ASCE J. Water Resour. Plan. Manag. 12, 114-127.

Ouranos, 2015. Vers l'adaptation. Synthèse des connaissances sur les changements climatiques au Québec. Partie 1: Évolution climatique au Québec, p. 114.

Padmanabhan, G., Bengtson, M.L., 2001. Assessing the influence of wetlands on flooding. In: Hayes, D.F. (Ed.), Process Wetlands Engineering and River Restoration, vol. 110 (Reno, Nevada).

Paquin, D., 2010. Évaluation du MRCC4 en passé récent (1961-1999). Ouranos, Équipe Simulations climatiques. Rapport interne no 15.

Peel, M.C., Finalayson, B.L., McMahon, T.A., 2007. Updated world map of the Köppen-Geiger climate classification. Hydrol. Earth Syst. Sci. 11, 1633-1644.
Quilbé, R., Rousseau, A.N., Moquet, J.-S., Trinh, N.B., Dibike, Y., Gachon, P., Chaumont, D., 2008. Assessing the effect of climate change on river flow using general circulation models and hydrological modelling - Application to the Chaudière river, Québec, Canada. Can. Water Resour. J. 33 (1), 73-94.

Rousseau, A., Lafrance, P., Lavigne, M.-P., Savary, S., Konan, B., Quilbé, R., 2008. Development of Achievable Agri-environmental Performance Standards (APS) in Five Canadian Watersheds. National Agri-environmental Standards Initiative Technical Series Report No. 4-30, p. 343.

Rousseau, A.N, Fortin, J-P, Turcotte, R, Royer, A Savary, S, Quévy, F, Noël, P. Paniconi, C., 2011. PHYSITEL, a specialized GIS for supporting the implementation of distributed hydrological models. Water News Off. Mag. Can. Water Resour. Assoc. 31 (1), 18-20.

Rousseau, A.N, Lafrance, P. Lavigne, M.-P. Savary, S, Konan, B, Quilbé, R, Amrani, M., Jiapizan, P., 2012. A hydrological modelling framework for defining watershed-scale achievable performance standards of pesticides beneficial management practices. J. Environ. Qual. 41 (1), 52-63.

Schwarz G, 1978. Estimating the dimension of a model. Ann. Stat 6 (2) 461-464.

Scinocca, J.F., McFarlane, N.A., Lazare, M., Li, J., Plummer, D., 2008. Technical Note: the CCCma third generation AGCM and its extension into the middle atmosphere. Atmos. Chem. Phys. 8, 7055-7074.

Singh, J., Knapp, H.V., Demissie, M., 2004. Hydrologic Modeling of the Iroquois River Watershed Using HSPF and SWAT. ISWS CR 2004-08. Champaign, Ill.: Illinois State Water Survey. Available at. http://www.sws.uiuc.edu/pubdoc/CR/ ISWSCR2004-08.pdf (accessed 26.02.14.).

Solomon, S., Qin, D., Manning, M., Chen, Z., Marquis, M., Averyt, K.B., Tignor, M., Miller, H.L., 2007. Climate Change 2007-The Physical Science Basis: Working Group I Contribution to the Fourth Assessment Report of the IPCC. Climate Change 2007. Cambridge University Press (2007).

Turcotte, R., Fortin, J.P., Rousseau, A.N., Massicotte, S., Villeneuve, J.P., 2001. Determination of the drainage structure of a watershed using a digital elevation model and a digital river and lake network. J. Hydrol. 240 (3-4), 225-242.

Turcotte, R., Fortin, L.G., Fortin, J.P., Fortin, V., Villeneuve, J.P., 2007. Operational analysis of the spatial distribution and the temporal evolution of the snowpack water equivalent in southern Quebec, Canada. Nord. Hydrol. 38 (3), 211-234.

Turcotte, R., Rousseau, A.N., Fortin, J.P., Villeneuve, J.P., 2003. A processed-oriented multiple objective calibration strategy accounting for model structure. In: Duan, Q., Gupta, V.K., Sorooshian, S., Rousseau, A.N., Turcotte (Eds.), Calibration of Watershed Models. American Geophysical Union, Washington, pp. 153-163.

Wang, X., Shang, S., Qu, Z., Liu, T., Melesse, A.M., Yang, W., 2010. Simulated wetland conservation-restoration effects on water quantity and quality at watershed scale. J. Environ. Manag. 91 (7), 1511-1525.

Wang, X., Yang, W., Melesse, A.M., 2008. Using hydrological equivalent wetland concept within SWAT to estimate streamflow in watersheds with numerous wetlands. Trans. ASABE 51 (1), 55-72.

Wu, K., Johnston, C.A., 2008. Hydrologic comparison between a forested and a wetland/lake dominated watershed using SWAT. Hydrol. Process. 22 (10), 1431-1442.

Yang, W. Wang, X., Liu, Y., Gabor, S., Boychuk, L., Badiou, P., 2010. Simulated environmental effects of wetland restoration scenarios in a typical Canadian prairie watershed. Wetl. Ecol. Manag. 18 (3), 269-279.

Yapo, P.O., Gupta, H.V., Sorooshian, S., 1996. Automatic calibration of conceptua rainfall-runoff models: sensitivity to calibration data. J. Hydrol. 181 (1-4), $23-48$.

Zedler, J.B., Kercher, S., 2005. Wetlands resources: status, trends, ecosystem services and restorability. Annu. Rev. Environ. Resour. 30, 39-74. 